\title{
The Representation of Heart in Sheikh Abd El Qurna Private Tombs during the $18^{\text {th }}$ Dynasty
}

\author{
Rasha M. Omran \\ Faculty of Tourism and Hotels - Fayoum University
}

\begin{abstract}
The current research was dedicated to shed light on the heart and its symbolism in the Ancient Egyptian conception; to study the importance of heart in Ancient Egyptian religion; to focus on the representation of heart in both daily and funerary scenes like heart necklace which is represented either worn by the tomb owner or offered to him in Sheikh Abd El Qurna private tombs; to spotlight on the religious symbolism of the different colors and numbers of heart in the scenes decorating the walls of Sheikh Abd El Qurna private tombs; to spotlight on the specific locations of heart in scenes and their relation with the Ancient Egyptian conception. as well as to focus on the chapters dedicated to the heart protection in the book of the Dead. The preliminary results indicated that heart was illustrated in different locations inside the tombs like on the walls of the hall, inner room, burial chamber and passage. Heart was represented in both the funerary scenes like purification and opening of the mouth and daily life scenes like offering food to the deceased in the $18^{\text {th }}$ dynasty private tombs at Thebes especially in Sheikh Abd El Qurna Necropolis.
\end{abstract}

Key Words: Heart, Sheikh Abd- el - Qurna, Ancient Egypt, Funerary Scenes, Daily Life Scenes, Religious Symbolism, Private Tombs, New Kingdom.

\section{Introduction}

God Ptah created the entire universe from the depths of his heart, so the heart was well-deserved to be the symbol of life, whether in mundane world or the heavenly one. ${ }^{1}$ Concerning the underworld judgment, the heart was balanced in the judgment court against the feather as a symbol of truth because truth was very light like feather in ancient Egyptian beliefs ${ }^{2}$ or against the statue of goddess MAat as a sign of truth and justice. In some other cases, the statue of the deceased replaced the heart against the justice symbol in the presence of Osiris, the god of the underworld referring to prudence and purity. ${ }^{3}$ It is very important to mention that from the $21^{\text {st }}$ Dynasty both of the heart and the eye as well as some other parts of the deceased body were represented on the scale as the innocence must be not only for the deceased but also for all parts of the body like eye, mouth, hands and legs. ${ }^{4}$ The walls of the private tombs at western Thebes are covered with such scenes for protecting the heart of the deceased as well as to be as a warranty for a fair judgment. ${ }^{5}$

\section{Objectives}

1. To shed light on the symbolism of heart in the Ancient Egyptian religion.

2. To study the importance of heart in the Ancient Egyptian conceptions.

3. To spotlight on the function of heart in the funerary scenes and daily life scenes represented on the walls of Ancient Egyptian Monuments especially the private tombs of Sheikh Abd El-Qurna at western Thebes.

4. To focus on the religious symbolism of the different colors of hearts.

5. To shed light on the religious significance of the different numbers of hearts hanging in the necklaces of the tomb owner.

6. To spotlight on the specific locations of heart scenes inside the Sheikh Abd El Qurna private tombs.

7. To focus on the chapters dedicated to speak about the heart protection in the Book of the Dead.

\section{Methodology}

This research depended on a descriptive approach which is applied to describe the daily life and funerary scenes illustrated on the walls of Sheikh Abd El Qurna private tombs at western Thebes. Also, it depended on an analytic approach to explain and comment on the details of the scenes.

\section{Sheikh Abd El Qurna}

It is considered one of the most popular non- royal cemeteries at western Thebes ${ }^{6}$ to the southeastern side of the temple of Deir El Bahari. ${ }^{7}$ Its name comes from a small tomb of a saint buried at that place. It is considered one of six cemeteries of private tombs on the western bank which are (Dra Abu El Naga, Khokha, Assasif, Sheikh Abd El Qurna, Qurnet Murai and Deir El Madina). ${ }^{8}$ It is characterized by containing the biggest number of the private tombs 
belonging to different periods from the $11^{\text {th }}$ to the $25^{\text {th }}$ dynasty; the total number of them is 144 tombs, 100 of which belong to the $18^{\text {th }}$ dynasty. Moreover, it is distinguished by the quality of its rock which is very appropriate for both painting and inscriptions. ${ }^{9}$ All these features help the researcher in her study and in collecting as much as scenes including the heart.

\section{Heart Amulet}

Ancient Egyptians believed in amulet's magical power and its important role to ensure life, health, rebirth and resurrection for the deceased in the netherworld. ${ }^{10}$ Amulet was given many names in hieroglyphs like sA, mkt and wDAw which mean to protect. ${ }^{11}$ It was a very tiny thing obtaining its magical power from its form, color as well as material. ${ }^{12}$ It is well known that heart amulets were carved from precious material like carnelian and lapis lazuli. ${ }^{13}$ It was used to be worn by the living person or the dead one to protect him from any evil facing him during his lifetime or in the nether world. ${ }^{14}$ Heart scarab was considered a very necessary amulet in the Ancient Egyptian conception as it was a symbol of rejuvenation and revival for its owner ${ }^{15}$ by placing it on the breast of his mummified body. ${ }^{16}$ It was used as a substitute for the original heart. ${ }^{17}$ Moreover, it gave the deceased the power of the creative God. ${ }^{18}$ It first appeared in the Ancient Egyptian art from the beginning of the New Kingdom. ${ }^{19}$ The heart amulet was considered to be one of the essential secured amulets in Ancient Egyptian beliefs. It appeared in Ancient Egypt with various shapes, sizes and materials, that is why it became so difficult to realize a general symbolism or significance for this type of amulets. ${ }^{20}$ It can be concluded that all the types of heart amulets were used to be as a symbol of healing, protection and power to avert evil influences of Seth. Besides, heart amulet was used after the process of weighing the heart to save the rebirth of the deceased ${ }^{21}$ and endow him with vindication in the hall of judgment. ${ }^{22}$

\section{Heart in the Book of the Dead}

The book of the dead was considered one of the Ancient Egyptian religious books. It consists of many funerary chapters or spells which were put in the tombs with the dead persons helping them to secure the continuity of their life in the hereafter. ${ }^{23}$ The most famous chapters are the chapters speaking about heart including for example; spell $26^{24}$ which was dedicated to give the heart to the dead person and help him in his life after death. ${ }^{25}$ Furthermore, by giving the heart to the deceased, he could have the complete power of life in the netherworld. ${ }^{26}$ Spell 27 was dedicated to prevent taking or turning the heart out of the deceased body in the presence of the underworld deities. ${ }^{27}$ The same was for spells 29, 29 A that referred to the same idea of the deceased' heart. ${ }^{28}$ Spells $30^{29}$, 30A and 30B were consecrated to prevent the heart disagreeing with its owner in front of the gods, to provide the deceased with help and protection throughout the divine judgment. ${ }^{30}$ Spell 125 was dedicated for the underworld judgment and weighing the heart on the balance against the sign of mAat. It included what can be called the exoneration announcement for the deceased. ${ }^{31}$

\section{Symbolism and colors in Ancient Egypt}

Symbolism is one thing that can replace something else not by the way of conformity but in a spiritual manner. According to the Ancient Egyptian conception, symbolism was very important because it was used in everything to protect the Ancient Egyptian during his life on earth and to make him secured from all dangers facing him in the netherworld. ${ }^{32}$ It is noticeable that the symbol is a physical thing that can give the meaning and its opposite at the same time. ${ }^{33}$ By using symbolism, the Ancient Egyptian could express most of his beliefs and thoughts of the Universe. ${ }^{34}$

Color was very important to the Ancient Egyptians as it was considered the essence of anything. In paintings, color was essential in reflecting both the function and sentimental manifestation. ${ }^{35}$ Besides, colors were used to express most of the symbolic concepts that were accompanied by religious ideas which were related to some deities and natural powers. ${ }^{36}$ In this research, heart is represented with many colors like black, white, red, yellow and blue. Each color has a specific symbolism and religious significance. Moreover, all the colors gave the meanings of resurrection, eternity, fecundity, facing dangers and overcoming the obstacles in the netherworld.

Black was called in hieroglyphs $\mathrm{Km}$ which means black, demise. ${ }^{38}$ It was also the sign of annihilation of severe foes. ${ }^{39}$ Black color refers to the underworld as it was the sign of Osiris, Anubis, Khenty Imntiu. God Min was represented several times painting in black as a sign of fecundity. ${ }^{40}$ It also referred to the fertile land or Upper Egypt which was called in hieroglyphs kmt that means black or fertile land. ${ }^{41}$ Black color also indicates resurrection and renewal. ${ }^{42}$ Red was called dSr ${ }^{2}$ in hieroglyphs. ${ }^{43}$ In Ancient Egypt, red was a unique color which had full effectiveness on human emotions. It referred to life, resurrection, triumph and power and that is why the Ancient Egyptians used to color their bodies with red color and wear jewellry with red stones during the festivals ${ }^{44}$ on one hand as well as aggression and threat on the other hand. ${ }^{45}$ In other words, it was considered a symbol of both good and bad things at the same time. It also referred to blood as a sign of life and power which is a good thing. On the Contrary, it was connected with Seth; the god of evil whose color was red and he was described in the late period as the red Hippopotamus. ${ }^{46}$ Red color was believed to be a sign of anger ${ }^{47}$, a symbol of danger as well as devastating fire. ${ }^{48}$ In Ancient Egypt, red and black colors were used instead of each other. They referred to the same significance of power, destruction of enemies, especially in the scenes representing the punishment of guilty people. In this case, red was a 
sign of bloody and black was the symbol of darkness that was faced by those people in the netherworld. ${ }^{49}$ Concerning red and white colors, the Ancient Egyptians believed that when red and white colors were found together, they gave another meaning as completeness, totality and integrity referring to the double crown of Upper and Lower Egypt that means the complete control over the whole country. ${ }^{50}$ White Color was called in hieroglyphs HD $\odot{ }^{51}$ that was a sign of purity, ${ }^{52}$ fecundity and saintliness. ${ }^{53}$ Yellow color was believed to be a very important color for the Ancient Egyptians as it was considered to be the symbol of continuity and immortality as it referred to the vast desert. ${ }^{54}$ Both yellow and white colors could replace each other in Ancient Egyptian Art because they were classified among the light colors. ${ }^{55}$ Finally, blue color was considered the sign of protection and fecundity. ${ }^{56}$ It was known in hieroglyphs as xsbd $\theta$ Өी $\iint_{000}^{\infty}$ which refers to Lapis lazuli in Ancient Egypt. ${ }^{57}$ It refers to God Amun whose color was blue symbolizing its cosmic manifestation and regeneration. ${ }^{58}$

\section{Doc. 1 Scene 1 (TT 61 - Amenuser (User) $1 \|^{-\infty}$ usr)}

This scene is represented in the inner room especially on the lower part of the northern wall which is mostly damaged. This part carries a large list of offerings, beneath which to the left, there is the final scene of the opening of the mouth ritual with sacrificial offerings to the right. This scene represents three men holding offerings like a goose, a heart and a bull's leg. ${ }^{59}$

\section{Doc. 2 Scene 2 (TT 83 - aAmethu}

On the west wall of the inner room IJ, most of the scenes are extremely damaged near side I except the scene which represents funeral procession facing the goddess of the west. ${ }^{60}$ The goddess in this scene is the personification of Hathor. ${ }^{61}$ The scene is divided into two registers containing men in boats preceded by shrines while the lower part of the wall is completely ruined. The first register represents two men on a boat, one of them holding a bull's leg with his right hand trying to pull some water and holding a heart in a vase on his left hand. This scene perhaps refers to removing both the heart and the leg of Osiris from the water. ${ }^{62}$

\section{Doc. 3 Scene 3 (TT 84 Amunedjeh 03}

The western wall of the passage is decorated with a scene divided into three registers. ${ }^{63}$ The first one represents crossing the Nile to the west bank during the funeral procession ${ }^{64}$ directed to the goddess of the west including a boat, a bull's leg, a heart as well as a shrine at the end. ${ }^{65}$ The second register includes a sub - scene representing the opening of the mouth ritual in front of a mummy in which there is the representation of a bull's leg and heart. ${ }^{66}$

\section{Doc. 4 Scene 4 (TT87 Minnakht}

The Southern wall of the inner room is decorated with a large figure of the tomb owner in a sitting position receiving papyrus plant from his son facing four registers. The uppermost register carries the deceased celebration in which the deceased stands in a booth with men from right to left, a priest holds incense and a libation vase, three butchers carry a bull's leg, head and a heart on plates as well as other three men carry chest as funerary equipment. ${ }^{67}$

\section{Doc. 5 Scene 5 (TT42 Amenmose}

The western wall of the passage is blank from the entrance for about twelve feet. Then, funeral procession scenes occupy the next eleven feet in five registers. The fourth register represents two men in a boat facing a shrine; one of them is shown holding a heart on his left hand and pulling some of water by a bull's leg. ${ }^{68}$

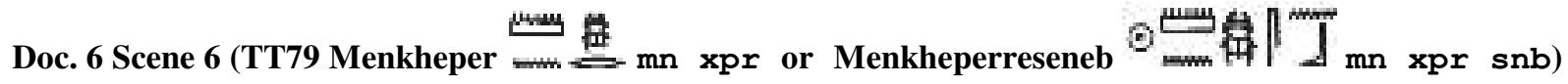

The Northern wall of the hall carries a scene representing the tomb owner with his family while watching a funerary equipment offered to him during the so - called deceased celebration in six registers. In the fifth register, there are four standing men; the third one from the right is shown holding a heart necklace with his left arm. ${ }^{69}$

\section{Doc. 7 Scene 7 (TT100 Rekhmirea $\theta$ औी}

The western wall of the passage has a scene (Scene 7a) which is divided into two sections; the left one contains ten registers representing divinities of funeral rites like Osiris, Anubis and the goddess of the west. ${ }^{70}$ In the second register which is directed to Osiris, a butcher is holding a heart in a vase with his left hand preceded by another one holding a bull's leg and followed by two others holding bulls' legs. The ninth register contains the butcher holding a heart on a 
plate with his left hand preceded by another on holding a bull's leg and facing the goddess of the west. ${ }^{71}$ The fifth register in the same scene shows a boat crossing the Nile directed to Anubis. ${ }^{72}$ In the boat there are two persons; one of them is holding a heart in a vase with his left hand and bull's leg with the right one. Concerning the right section, it includes four registers representing the deceased meal offerings. The fourth register represents the owner of the tomb with his wife Meryt ${ }^{73}$ in front of an offering table receiving offerings from persons, one of them holds a heart in a vase with his right hand preceded by another one holding a bull's leg. The eastern wall of the passage is decorated with a scene (Scene 7b) also divided into two parts; the left one contains four registers representing the deceased meal offerings. In the fourth register, it can be seen a person presenting a heart in a vase with his left hand to the tomb owner and his wife Meryt. The right part is covered with many of ritual performances for the statues of the deceased represented in ten registers ${ }^{74}$ in order to give the deceased statue or mummy the power of a living person like opening of the mouth ritual that is represented in the fourth register before the statue of the deceased. ${ }^{75}$ In the middle of this register, it can be seen butchers, one of them is holding a bull's leg and the other is carrying a heart in a vase with his both hands to the deceased statue.

\section{Doc. 8 Scene 8 (TT78 Horemheb $\mathrm{A} \subset ?\rfloor_{\mathrm{Hr}-\mathrm{m}-\mathrm{Hb})}$}

The western wall of the passage is covered with funeral scenes that are divided into four registers. The second one includes a funeral equipment scene at the end of which a person holding a scarab necklace (most probably heart) is represented. ${ }^{76}$

Doc. 9 Scene 9 (TT29 Amenemopet

The northern wall of the passage contains two registers including a funeral procession in front of the owner of the tomb. The scene includes persons catching goats and bulls in addition to butchers in a sacrifice scene which is severly damaged. ${ }^{77}$ Concerning the sacrifice scene, it can be suggested that the butchers were most probably carrying a heart of the bull as a sacrifice offering like the same scenes represented in other nobles' tombs in the same period.

\section{Doc. 10 Scene 10 (TT104 Dhutnufer}

The northern wall of the inner room is decorated with opening of the mouth scene covering three registers and partly destroyed. ${ }^{78}$ The scene in the second register includes many rituals performed in front of the tomb owner's mummy like sacrifice in which there are two persons standing and presenting both the bull's leg and heart in a vase to the mummy. ${ }^{79}$

\section{Doc. 11 Scene 11 (TT96 Sennefer th sn-nfr)}

The Passage is decorated with three scenes as follows; on the southern wall there is a scene (Scene 11a) presenting the tomb owner wearing a double heart necklace and a bunch of Amun to his brother Pairi. ${ }^{80}$ The northern wall represents two scenes (Scene 11b, 11c) representign the deceased wearing double heart necklaces as the watcher of land products and a banquet held for him. ${ }^{81}$ The antechamber includes three scenes like scenes $(11 \mathrm{~d}, 11 \mathrm{f})$ on the western and eastern walls that represent the deceased observing a funerary equipment wearing a double heart necklace (Scene11f) ${ }^{82}$ On other hand, the southern wall represents the deceased in a standing position back to back (Scene 11e) wearing a double heart necklace. ${ }^{83}$ The burial chamber includes two scenes; the first one on the western side (Scene 11g) representings crossing the Nile by a boat in which a person is holding a heart in a vase on his left hand. ${ }^{84}$ On the eastern wall, it can be seen the priest purifying the deceased who is wearing a double heart necklace (Scene 11h) ${ }^{85}$ The burial chamber contains four pillars with many scenes including hearts like pillar F (c) which includes one scene (Scene11i) that represents the deceased receiving myrrh from his wife. ${ }^{86}$ It should be mentioned that sen-nefer is shown wearing a double heart necklace. Pillar ( $\mathrm{H} \mathrm{a}, \mathrm{b}, \mathrm{c}$ and $\mathrm{d})$ has four scenes on all its sides; three of them represent the wife of the tomb owner offering to him a cup (Scene 11j), a necklace (Scene 11k) and pectorals (Scene 111). On the other hand, the fourth side of the pillar represents the deceased surrounded by four priests purifying him ${ }^{87}$ (Scene $11 \mathrm{~m}$ ). It is noticeable that sen-nefer is represented in all scenes wearing a double heart necklace. Finally, Pillar G (b) has only one scene (Scene $11 \mathrm{n}$ ) representing the deceased wearing a double heart necklace sitting in front of his wife ${ }^{88}$ who is represented in a standing position with nothing in their hands.

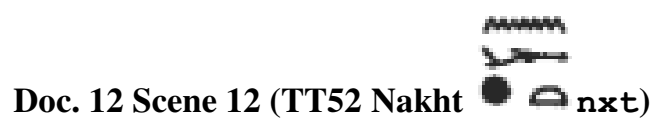

The eastern wall of the hall is covered with a scene which is divided into two registers; the first of which represents priests holding unguents and thin flames as well as offering bearers. The second register represents four priests in a standing position presenting offerings to the deceased and his wife. One of the priests is shown holding a bull leg with the left hand and a big heart with his right hand. ${ }^{89}$ 
Doc. 13 Scene 13 (TT63 Sebekhotep I J

The southern part of the passage is decorated with a scene which is divided into three parts. The middle part of the scene has six registers, the sixth of which contains a boat crossing the Nile to the western side including two persons; ${ }_{90}$ one of them is shown holding a heart on the left hand and trying to pull water with the leg of a bull with the right hand.

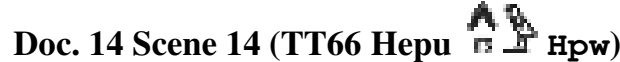

The western wall of the inner room is covered with four registers partly damaged, containing remains of funeral scenes. The lowest scene represents men with funerary equipment including a person to the right holding a heart on a plate and offering it most probably to the deceased. ${ }^{91}$

\section{Doc. 15 Scene 15 (TT69 Menna}

The Southern wall of the inner room is covered with four registers; the upper two registers are directed to the western goddess, while the lower ones are directed to the mummification god Anubis. The third register represents crossing the Nile by a boat in which a person is holding a heart on a plate with his left hand and the leg of a bull with his right hand. 92

\section{Doc. 16 Scene 16 (TT57 KhaaemHet}

The eastern wall of the passage is decorated with a scene representing the tomb owner wearing a heart long necklace surrounded by the Djed pillar and the knot of Isis. ${ }^{93}$

\section{Doc. 17 Scene 17 (TT55 Ramose I /f Ra-ms)}

The eastern wall of the hall is covered with the purification ritual for the statue of the tomb owner which is represented in a standing position and two priests are shown purifying it. ${ }^{94}$

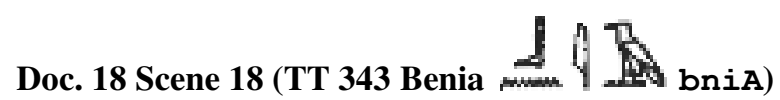

The northern wall of the inner room is decorated with the opening of the mouth scene in which there is a slaughter scene representing the butcher and the priest while holding a leg bull and heart. ${ }^{95}$ 


\section{Study Analysis}

Table (1) Representation of Heart in Sheikh Abd El Qurna Private Tombs during the $18^{\text {th }}$ Dynasty

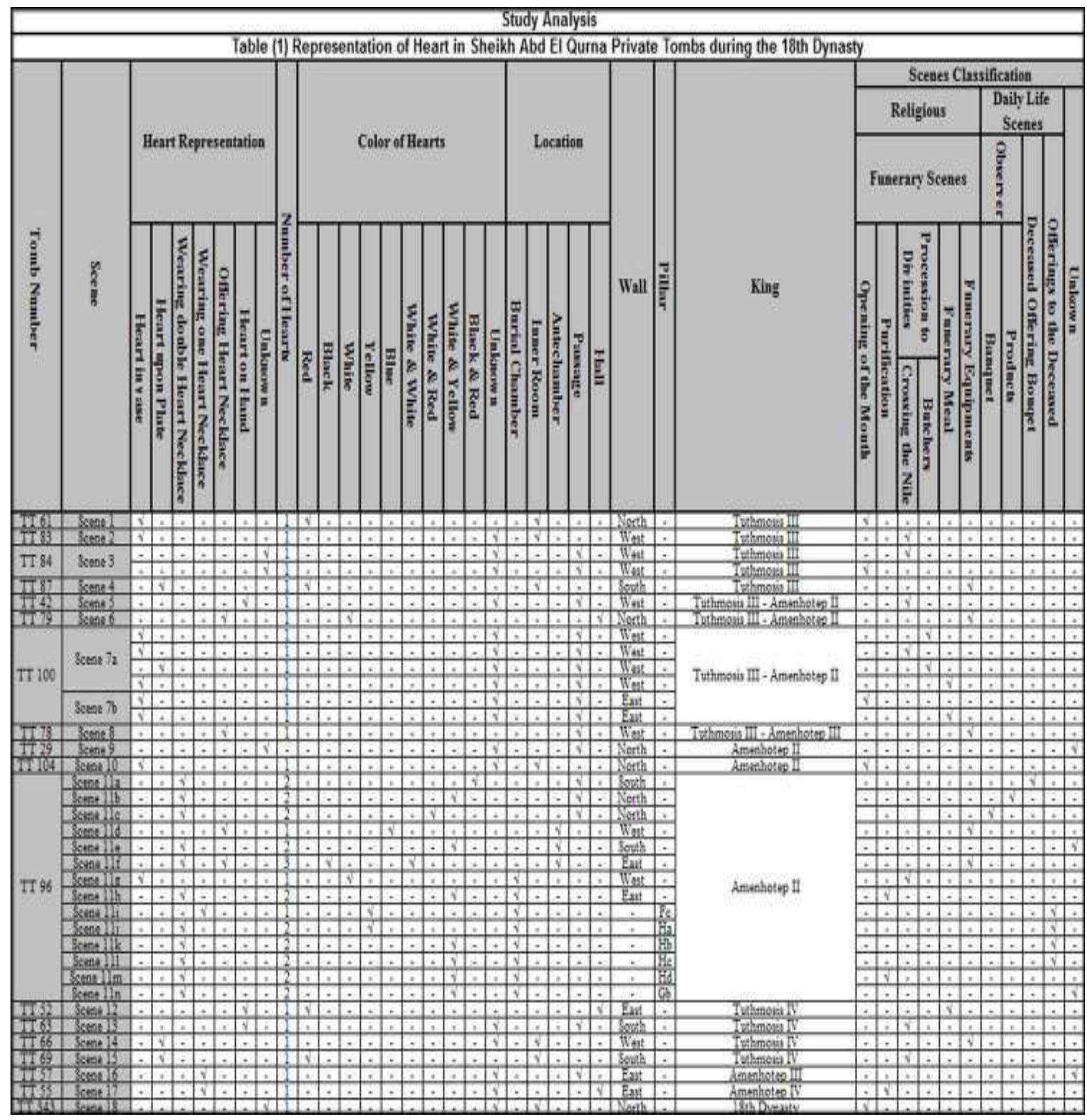




\section{Discussion}

According to the attached table, it can be concluded that heart is represented through two types of scenes; funerary and daily life.

\section{Firstly: Funerary Scenes}

Funerary Scenes were the most familiar scenes in the New kingdom tombs as they were represented on the walls of the longitudinal corridor (Passage) until the reign of Amenhotep III as they were illustrated on the walls of the transverse hall. ${ }^{96}$ Funerary scenes included many consecutive events starting with purification process, mummification, and transportation of the deceased body to the tomb through a funerary procession after the pilgrimage to Abydos then opening of the mouth ritual in front of the tomb as one of the burying rituals. ${ }^{97}$

\section{1-Opening of the Mouth}

This ritual was acted in front of the tomb in order to enable the deceased to speak, eat, see, hear and move again in the netherworld as well as it helps him to retrieve all his power and abilities in addition to preparing him with magic to face the dangers afterlife. ${ }^{98}$ It didn't appear in the $18^{\text {th }}$ dynasty tombs on a large scale until the reign of Tuthmosis III. ${ }^{99}$ It is very important to mention that there were many successive steps in the process of opening of the mouth as sacrificial rituals to the Upper and Lower Egypt in which the priests offered the heart and the foreleg of the bull to the mummy or the statue of the deceased. ${ }^{100}$ Heart is represented five times in the scene of the Opening of the mouth which is depicted three times on the northern wall of the inner room and two times on the eastern and western walls of the passage. Heart is shown three times held in a vase. See (Scenes $1,3,7 \mathrm{~b}, 10,18$ ).

\section{2- Purification}

The purification process started immediately after death by pouring water on the mummy. It was considered the first step for the deceased body care. The aim of this process was to preserve all the parts of the body, to revive and rebirth it in the netherworld. ${ }^{101}$ Heart is shown three times in a purification scene which is depicted one time on the eastern wall of the burial chamber and the hall. It is also represented one time on the wall of the burial chamber pillar. Heart in the purification scene is usually represented either in the form of a double heart necklace worn by the tomb owner with white and yellow colors for two times and once as only one heart necklace with unknown color. See (Scenes $11 \mathrm{~h}, 11 \mathrm{~m}$, 17).

\section{3- Procession to Divinities (Crossing the Nile - Butchers)}

Procession to Divinities was considered a part of the funerary ritual illustrated on the walls of the $18^{\text {th }}$ dynasty tombs overseen by three deities like Anubis, Osiris and the western goddess into three or four registers. The most famous scene of this type is represented in the tomb of Rekhmire no.100. ${ }^{102}$ Procession to Divinities includes many scenes like crossing the Nile by boats and other scenes representing butchers holding hearts in their hands. The scenes of crossing the Nile count seven in number that are represented in different locations of the tombs like the passage, the inner room and the burial chamber. The scene is depicted five times on the western wall; three of them in the passage, once in the inner room and once in the burial chamber. It is also shown twice on the southern wall: one in the passage and the other in the inner room. The heart in crossing the Nile scene is usually represented single in number either in vase that is repeated three times, upon plate for about one time or carried on hand for two times. The heart color which is unknown in most of this type of scenes reached five in number but it is red in one case and white in an other one. See (Scenes 2, $3,5,7 \mathrm{a}, 11 \mathrm{~g}, 13,15)$. Concerning butchers, they are represented twice on the western wall of the passage with unknown color and single in number either in a vase or upon a plate. See (Scene 7a).

\section{4- Funerary Meal}

This scene is usually shown following the funerary procession scene. It was dedicated to the owner of the tomb and his wife in which the deceased's son is represented wearing priest cloth and offering food to his parents. ${ }^{103}$ This scene is represented three times; twice in TT 100 and once in TT 52. The heart is shown twice on the eastern and western wall of the passage and one on the eastern wall of the hall. In all of the funerary meal scenes, the heart is single in representation either in a vase or on a hand. See (Scenes $7 \mathrm{a}, 7 \mathrm{~b}, 12)$.

\section{5- Funerary Equipment}

It was considered a part of the funerary procession that was represented on the walls of the $18^{\text {th }}$ dynasty tombs. It includes the funerary furniture' bearers, mourners, the coffin of the deceased on a sledge pulled by bulls. ${ }^{104}$ It is noticed that this scene is repeated six times in different locations and different directions. The funerary equipment scenes are shown three times on the western wall of the passage, the antechamber and the inner room. It is also represented on the northern wall of the hall, eastern wall of the antechamber and southern wall of the inner room. It is noticed that the heart in this type of scenes is represented taking different colors. The heart is shown four times taking the form of a heart 
necklace offering to the deceased, twice in the form of a heart upon plate and once as a double heart necklace. See (Scenes 4, 6, 8, 11d, 11f, 14).

\section{Secondly: Daily Life Scenes}

Daily life scenes were very familiar scenes in the private tombs in general and in the New Kingdom tombs in particular.
105

\section{1- Observer (Banquet - Products)}

Daily life scenes include different scenes representing the tomb owner acting various activities during his lifetime upon earth. In this type of scenes, the deceased is shown as the observer once of the banquet and once of products on the northern wall of the passage wearing a double heart necklace of white and red color in the first case and white and yellow in the second case. See (Scenes 11c, 11b).

\section{2- Deceased offering Bouquet}

This scene is represented once on the southern wall of passage in which the deceased is shown wearing a double heart necklace with black and red colors. See (Scene 11a).

\section{3- Offerings to the Deceased}

This type of scenes is repeated four times on the pillars of the burial chamber in only one tomb which carries no. 96 of sen-nefer. The heart in these scenes is represented as a necklace worn by the tomb owner who is shown receiving the offerings from his wife. Three of these necklaces are double except one that is single with white and yellow colors. See (Scenes $11 \mathrm{i}, 11 \mathrm{j}, 11 \mathrm{k}, 11 \mathrm{l})$. It is noticeable that the burial chamber of sen - nefer is completely depicted with different scenes either on the walls or on the pillar, most of which for his wife while offering to him. ${ }^{106}$ Finally, there are unknown scenes that can not be classified: they are four in number and they are represented in three tombs TT 29, TT 96, TT 57. See (Scenes 9, 11e, 11n, 16). 


\section{Results}

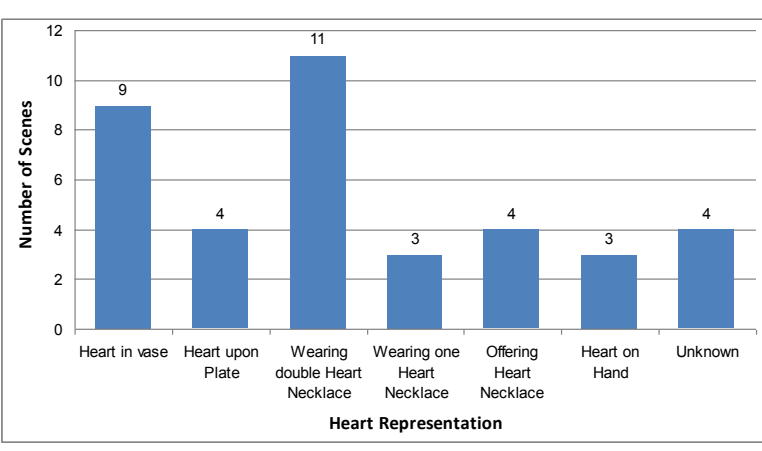

Chart 1

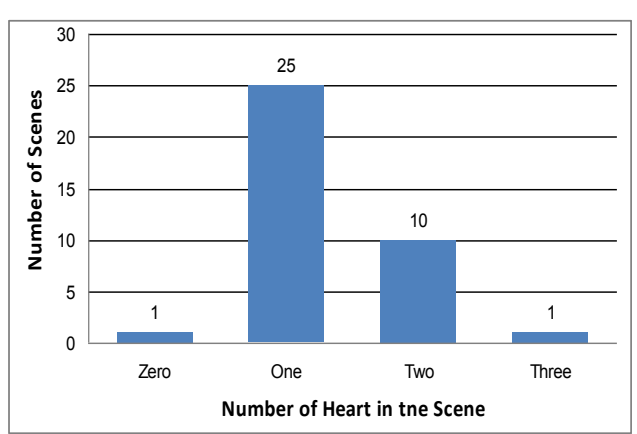

Chart 2

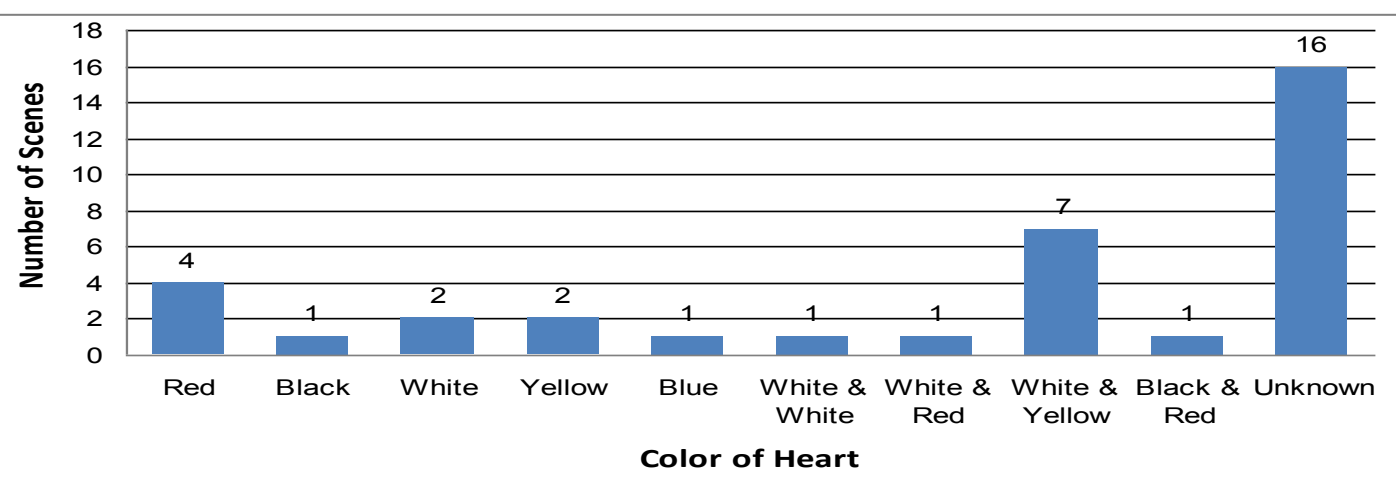

Chart 3
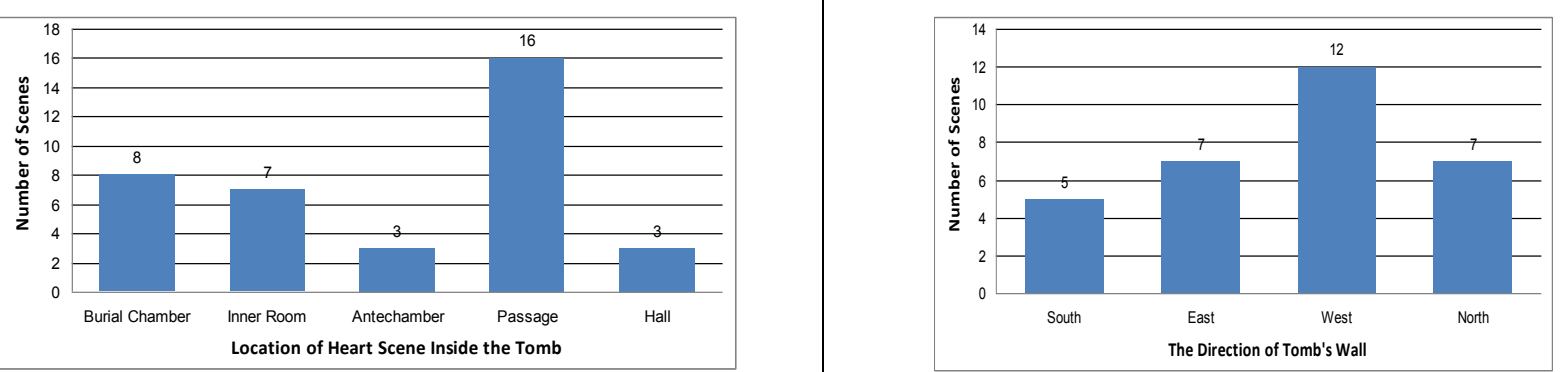

Chart 4

Chart 5

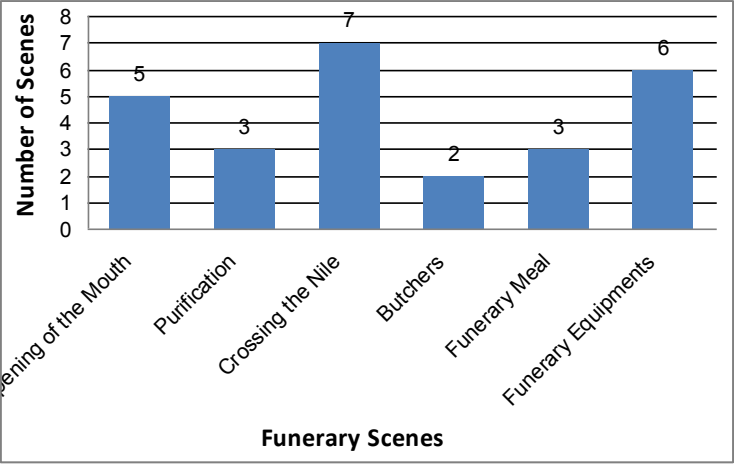

Chart 6

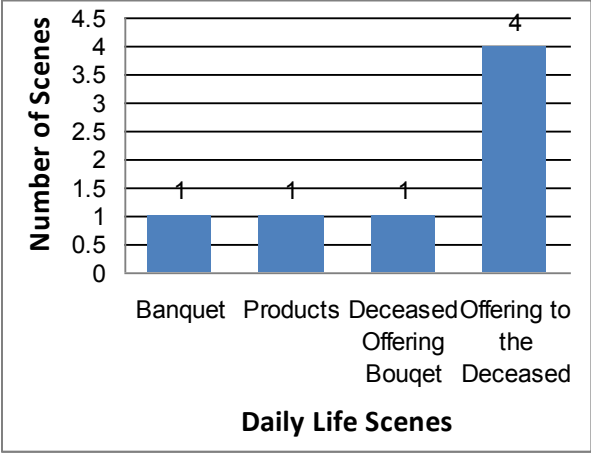

Chart 7 
According to Charts (1-7), it can be noticed that heart appears in six representations (Chart 1); four of them vary in appearance from 3 to 4 numbers except for two representations of wearing a double heart necklace and heart in a vase which are repeated 11 and 9 times respectively. Heart is represented single in 25 scenes and double in 10 which is considered the majority of heart numbers in the scenes (Chart 2). Heart is represented with different colors like red, black, white, yellow and blue (Chart 3). It is obvious that the most preferable color for the Ancient Egyptians was white and yellow then red while both black and blue were not favorite for them as each one of these colors appears only one time. Heart scenes are depicted in different places of the $18^{\text {th }}$ dynasty tombs of Sheikh Abd El Qurna (Chart 4) especially the passage. It is very important to mention that heart appears eight times only on the walls of the burial chamber and on the walls of the four pillars of sen- nefer most of relate to the owner and his wife while offering to him. It can be noticed that heart scenes appear 16 times on the walls of the passages in comparison to the hall in which heart scenes are shown only 3 times. It is very clear that funerary scenes reached 26 in number (Chart 6) that is why the western direction's wall is covered with 12 scenes (Chart 5) compared to the other directions because there was a relationship between the netherworld and the west in Ancient Egyptian conception. Finally daily life scenes (Chart 7) reached 7 in number of which scenes representing offering to the deceased occupy the biggest number. In general, heart was believed to be the way to immortality and the only organ that helped the deceased to survive in the afterlife where it gave proof against or for its owner. In the Book of the Dead In Spell 30, the deceased asked his heart not to witness against him, thus indicating the importance of the heart in deciding the deceased's fate in the other world. The representation of heart was illustrated in different locations of ancient Egyptian New kingdom private tombs in Sheikh Abd El Qurna like the inner room, transverse hall and Longitudinal Corridor. Concerning the burial chambers during the $18^{\text {th }}$ dynasty, they were very rarely depicted with scenes and that is why heart was not represented in the burial chambers of Sheikh Abd El Qurna tombs except for the burial chamber of sen- nefer especially its pillars. ${ }^{107}$ The heart was represented in religious scenes especially funerary ones such as purification of the deceased, the funerary procession and daily life scenes like representing offering food to the deceased in the New Kingdom private tombs of Sheikh Abd El Qurna. The heart was represented in different colors with different religious significances. Heart pendants were varied in numbers as represented in the heart necklaces worn by the tomb owner. The heart was mentioned in different spells from (26 to 30) in the Book of the Dead. The nobles of the 18th dynasty used to illustrate daily life scenes on the walls of the hall and the funerary scenes on the walls of the passage except for some abnormal cases like the tomb TT 55 of Ramose in which the purification scene is represented decorating the eastern wall of the hall. Heart scenes are represented in only 19 tombs relating to Tuthmosis III, Amenhotep II, Tuthmosis IV, Amenhotep III and Amenhotep IV. Most of the scenes shown in the tombs belong to both Tuthmosis III and Amenhotep II. It is noticeable that around 14 heart scenes are represented in the tomb of sen- nefer in comparison to the other tombs most probably because of its big size and the good condition of the tomb in general and its scenes in particular. In the opening of the mouth scene, the foreleg of the bull is usually represented accompanying the heart in order to help the deceased to face dangers in the netherworld as the foreleg was considered a sign of Seth god of evil in Ancient Egypt.

\section{Methods of Making the Research Useful for Tourism Guidance}

- Introducing a very important religious subject (Representation of Heart) in the private tombs at western Thebes especially Shehikh Abd El Qurna dating back to the New Kingdom.

- At the request of the General Tourist Guides Syndicate to increase the religious subjects and make them an important part of future research plans for the Tourism Guidance departments at the Faculties of Tourism and Hotels.

\section{Conclusion}

Heart played a very important role in determining the netherworld fate of the deceased person, whether happiness or misery. Because the ancient Egyptians believed in the resurrection and immortality, the Egyptian society was characterized by its upscale ethics that is consistent with all the monotheistic religions which believe that the lack of faith in the resurrection and the netherworld leads to the total collapse of the whole moral system

\section{Scene Index}

\section{Scene 1}

Dziobek, E. (1994), Die Graber des Vezirs User-Amun Theben Nr. 61 und 131, Mainz, Taf. 3b, 60 (scene 61-5).

\section{Scene 2}

Virey, PH. (1891) Sept Tombeaux Thébains de la XVIIIe Dynastie, (MMAF 5, 2). Paris, p. 348, Fig 2. 
Scene 3

El Shahawy, A. M. A. (2004), A Study of the Funeral Procession Scenes in the New Kingdom Nobles' Tombs in Thebes, Unpublished Thesis, Helwan University, Cairo, pls. 38-39 (not found).

\section{Scene 4}

Guksch, H. (1995), Die Gräber des Nacht-Min und des Men-cheper-Ra-seneb Theban Nr. 87 und 79, Mainz, Taf. 12, Scene.21.

\section{Scene 5}

Davies, N, G. and Davies, N. G. (1933), The Tombs of Menkheperrasonb, Amenmose and Another, London, Pl. XXXVIII.

$$
\text { عبد الرحيم محمد عبد المحسن طايع (2009)، أشكال ورموز الأبدية فى مقابر أثر اف الأسرة الثامنة عشرة بطيبة الغربية، رسالة ماجستير غير منشورة، }
$$

\section{Scene 6}

Guksch, H. (1995), Die Gräber des Nacht-Min und des Men-cheper-Ra-seneb Theban Nr. 87 und 79, Mainz, Taf. 43a, Scene.10.

\section{Scene 7(a)}

Davies, N. G. (1935), Paintings from the Tomb of REKH-MI-REa at Thebes, Vol. 10, New York, Pl. XXIV.

David, N. G. (1943), The Tomb of REH-MI-REa at Thebes, Vol. 1, New York, Pls. LXXXII, XC, XCI, XCII.

Virey, PH. (1889) Le Tombeau de Rekhmara, (MMAF 5, 1), Paris, Pls. XIX, XXI, XXII, XXVI.

\section{Scene 7(b)}

Davies, N. G. (1935), Paintings from the Tomb of REKH-MI-REa at Thebes, Vol. 10, New York, Pl. XXV.

Davies, N. G. (1943), The Tomb of REH-MI-REa at Thebes, Vol. 1, New York, Pls. CVI, CVIII.

Virey, PH. (1889) Le Tombeau de Rekhmara, (MMAF 5, 1), Paris, Pls. XXX, XXXII.

\section{Scene 8}

Annelies and Brack, A. (1980), Das Grab des Haremheb Theben Nr. 78, Mainz, Taf. 62b.

Bourian, U. (1894), Tombeaux Thebaines, MMAF (5, 3), Paris, Planche V.

\section{Scene 9}

Davies, N. G. (1913), Five Theban Tombs, London, Pl. XLIII.

El Shahawy, A. M. A. (2004), A Study of the Funeral Procession Scenes in the New Kingdom Nobles' Tombs in Thebes, Unpublished Thesis, Helwan University, Cairo, Pl. 109 (not found).

\section{Scene 10}

Shedid, A. G. (1988), Stilder Grabmalereien in der Zeit Amenophis' II, Untersucht an den Thebanischen Gräbern Nr. 104 und Nr. 80, Mainz, Taf. 28b, 29 b

\section{Scene 11(a)}

http://www.osirisnet.net/tombes/nobles/sennefer/e_sennefer_04.htm (Last Accessed 15/05/2016).

\section{Scene 11(b)}

http://www.osirisnet.net/tombes/nobles/sennefer/e_sennefer_04.htm (Last Accessed 15/05/2016).

\section{Scene 11(c)}

http://www.osirisnet.net/tombes/nobles/sennefer/e_sennefer_04.htm (Last Accessed 15/05/2016).

\section{Scene 11(d)}

$$
\text { عبد الرحيم محمد عبد المحن طايع (2009)، أثكال ورموز الأبدية فى مقابر أشر اف الأسرة الثامنة عشرة بطيبة الغربية، رسالة ماجستير غير منشورة، }
$$

\section{Scene 11(e)}

http://www.osirisnet.net/tombes/nobles/sennefer/e_sennefer_06.htm (Last Accessed 15/05/2016). 


\section{Scene 11(f)}

Noblecourt, C. D. and others (1986), Sen-nefer Die Grabkammer des Bürgermeisters von Theban, Mainz, pp. 25, 26.

Wulleman, R. and others (1989), Passage to Eternity, Belgium, p. 82.

$$
\text { عبد الرحيم محمد عبد المحسن طايع (2009)، أشكال ورموز الأبدية فى مقابر أشراف الأسرة الثامنة عشرة بطيبة الغربية، رسالة ماجستير غير منشورة، }
$$

\section{Scene 11(g)}

http://www.osirisnet.net/tombes/nobles/sennefer/e_sennefer_07.htm (Last Accessed 15/05/2016).

El Shahawy, A. M. A. (2004), A Study of the Funeral Procession Scenes in the New Kingdom Nobles' Tombs in Thebes, Unpublished Thesis, Helwan University, Cairo, Pl. 117 (not found).

\section{Scene 11(h)}

Noblecourt, C. D. and others (1986), Sen-nefer Die Grabkammer des Bürgermeisters von Theban, Mainz, pp. 38,58.

Abu El Magd, A. M. (2006), A Study of Opening of the Mouth Ritual scenes in the Nobles' Tombs in Thebes (New Kingdom), Vol. 1, Text, Unpublished Thesis, Helwan University, Cairo, Pl. LXXXVII (not found).

Wulleman, R. and others (1989), Passage to Eternity, Belgium, p. 81.

$$
\text { جامعة الفيوم، شحمد عبد المحسن طايع (2009)، أشكال ورموز الأبدية فى مقابر أشر اف الأسرة الثامنة عشرة بطيبة الغربية، رسالة ماجستير غير منشورة، }
$$

\section{Scene 11(i)}

http://www.osirisnet.net/tombes/nobles/sennefer/e_sennefer_09.htm (Last Accessed 15/05/2016).

\section{Scene 11(j)}

Noblecourt, C. D. and others (1986), Sen-nefer Die Grabkammer des Bürgermeisters von Theban, Mainz, p. 52.

Wulleman, R. and others (1989), Passage to Eternity, Belgium, p. 83.

\section{Scene 11(k)}

Noblecourt, C. D. and others (1986), Sen-nefer Die Grabkammer des Bürgermeisters von Theban, Mainz, p. 50.

Scene 11(1)

Noblecourt, C. D. and others (1986), Sen-nefer Die Grabkammer des Bürgermeisters von Theban, Mainz, p. 47.

\section{Scene 11(m)}

Noblecourt, C. D. and others (1986), Sen-nefer Die Grabkammer des Bürgermeisters von Theban, Mainz, p. 55.

\section{Scene 11(n)}

Noblecourt, C. D. and others (1986), Sen-nefer Die Grabkammer des Bürgermeisters von Theban, Mainz, p. 39.

\section{Scene 12}

Shedid, A. and Seidel, M. (1991), Das Grab des Nacht, Mainz, p. 74, 75.

Davies, N. G. (1917), The Tomb of Nakht at Thebes, New York, Pl. XIII, XIV.

\section{Scene 13}

Deziobek,E and Abd Elraziq, M (1990), Das Grab des Sobekhotep Theben Nr. 63, Mainz, Taf. 39.

\section{Scene 14}

Davies, N. G. (1963), Scenes from Some Theban Tombs, Vol. IV, Oxford, Pl. XIII

$$
\text { عبد الرحيم محمد عبد المحسن طايع (2009)، أثكال ورموز الأبدية فى مقابر أشر اف الأسرة الثامنة عشرة بطيبة الغربية، رسالة ماجستير غير منشورة، }
$$

\section{Scene 15}

Hartwig, M. (2013), The Tomb Chapel of Menna (TT 69), Cairo, pp. 68, 69, Fig. 2.14a.

$$
\text { جامعة الرحيم محمد شكل عبد المحسن طايع (2009)، أشكال ورموز الأبدية فى مقابر أشر اف الأسرة الثامنة عشرة بطيبة الغربية، رسالة ماجستير غير منشورة، }
$$


Scene 16

http://www.griffith.ox.ac.uk/gri/4khaem.html (Last Accessed 20/05/2016), Squeeze 4.38

(http://www.griffith.ox.ac.uk/gri/gif-files/gisqueeze_4_38.jpg)

Scene 17

Davies, N. G. (1941), The Tomb of the Vizier Ramose, London, Pl. XXI.

Hoenes, S. H. (2000), Life and Death in Ancient Egypt, London, p. 63, Fig. 34.

$$
\text { عبد الرحيم محمد عبد المحسن طايع (2009)، أشكال ورموز الأبدية فى مقابر أثشر اف الأسرة الثامنة عشرة بطيبة الغربية، رسالة ماجستير غير منشورة، }
$$

جامعة الفيوم، شكل 101 (

\section{Scene 18}

Abu El Magd, A. M. (2006), A Study of Opening of the Mouth Ritual scenes in the Nobles' Tombs in Thebes (New Kingdom), Vol. 1, Text, Unpublished Thesis, Helwan University, Cairo, Pls. LXVII, LXXIII (not found).

\section{Plan Index}

\section{Plan 1}

Dziobek, E. (1994), Die Graber des Vezirs User-Amun Theben Nr. 61 und 131, Mainz, p. 21.

Kampp, F. (1996), DieThebanische Nekropole. Zum Wandel des Grabgedankens von der XVIII. bis zur XX. Dynastie, Theben, 13, Vol. I, Mainz, p. 378, Fig. 165.

Porter, B. and Moss, R. (1960), Vol. 1, P.1, Oxford, p. 124.

\section{Plan 2}

Virey, PH. (1891) Sept Tombeaux Thébains de la XVIIIe Dynastie, (MMAF 5, 2). Paris, p. 237.

Kampp, F. (1996), DieThebanische Nekropole. Zum Wandel des Grabgedankens von der XVIII. bis zur XX. Dynastie, Theben, 13, Vol. I, Mainz, p. 333, Fig. 214.

Porter, B. and Moss, R. (1960), Vol. 1, P.1, Oxford, p. 160 .

\section{Plan 3}

Gnirs, A. M., Grothe, E.and Guksch, H. (1997), Zweiter Vorbericht über die Aufnahme und Publikation von Gräbern der 18. Dynastie der thebanischen Beamtennekropole, MDAIK 46, Mainz, p. 71, Abb. 3.

Abu El Magd, A. M. (2006), A Study of Opening of the Mouth Ritual scenes in the Nobles' Tombs in Thebes (New Kingdom), Vol. 1, Text, Unpublished Thesis, Helwan University, Cairo, p. 113, Fig. 79.

El Shahawy, A. M. A. (2004), A Study of the Funeral Procession Scenes in the New Kingdom Nobles' Tombs in Thebes, Unpublished Thesis, Helwan University, Cairo, p. 35, Fig. 13.

Kampp, F. (1996), DieThebanische Nekropole. Zum Wandel des Grabgedankens von der XVIII. bis zur XX. Dynastie, Theben, 13, Vol. I, Mainz, p. 335, Fig. 217.

Porter, B. and Moss, R. (1960), Vol. 1, P.1, Oxford, p. 160 .

\section{Plan 4}

Guksch, H. (1995), Die Gräber des Nacht-Min und des Men-cheper-Ra-seneb Theban Nr. 87 und 79, Mainz, Taf. 51 Porter, B. and Moss, R. (1960), Vol. 1, P.1, Oxford, p. 176.

Kampp, F. (1996), DieThebanische Nekropole. Zum Wandel des Grabgedankens von der XVIII. bis zur XX. Dynastie, Theben, 13, Vol. I, Mainz, p. 319, Fig. 205

\section{Plan 5}

Davies, N, G. and Davies, N. G. (1933), The Tombs of Menkheperrasonb, Amenmose and Another, London, Pl. XXXII.

Kampp, F. (1996), DieThebanische Nekropole. Zum Wandel des Grabgedankens von der XVIII. bis zur XX. Dynastie, Theben, 13, Vol. I, Mainz, p. 239, Fig 136.

Porter, B. and Moss, R. (1960), Vol. 1, P.1, Oxford, p. 80.

Abu El Magd, A. M. (2006), A Study of Opening of the Mouth Ritual scenes in the Nobles' Tombs in Thebes (New Kingdom), Vol. 1, Text, Unpublished Thesis, Helwan University, Cairo, p. 90, Fig. 65 


\section{Plan 6}

Guksch, H. (1995), Die Gräber des Nacht-Min und des Men-cheper-Ra-seneb Theban Nr. 87 und 79, Mainz, Taf. 52

Porter, B. and Moss, R. (1960), Vol. 1, P.1, Oxford, p. 148.

Kampp, F. (1996), DieThebanische Nekropole. Zum Wandel des Grabgedankens von der XVIII. bis zur XX. Dynastie, Theben, 13, Vol. I, Mainz, p. 319, Fig. 205

\section{Plan 7}

Kampp, F. (1996), DieThebanische Nekropole. Zum Wandel des Grabgedankens von der XVIII. bis zur XX. Dynastie, Theben, 13, Vol. I, Mainz, p. 373, Fig. 252.

Porter, B. and Moss, R. (1960), Vol. 1, P.1, Oxford, p. 208.

Virey, PH. (1889) Le Tombeau de Rekhmara, (MMAF 5, 1), Paris, p. 2.

Davies, N. G. (1935), Paintings from the Tomb of REKH-MI-REa at Thebes, Vol. 10, New York, Pl. XXI.

\section{Plan 8}

Porter, B. and Moss, R. (1960), Vol. 1, P.1, Oxford, p. 148.

Kampp, F. (1996), DieThebanische Nekropole. Zum Wandel des Grabgedankens von der XVIII. bis zur XX. Dynastie, Theben, 13, Vol. I, Mainz, p. 317, Fig. 203.

Annelies and Brack, A. (1980), Das Grab des Haremheb Theben Nr. 78, Mainz, p. 22, Abb. 1.

El Shahawy, A. M. A. (2004), A Study of the Funeral Procession Scenes in the New Kingdom Nobles' Tombs in Thebes, Unpublished Thesis, Helwan University, Cairo, p. 62, Fig. 24.

\section{Plan 9}

Porter, B. and Moss, R. (1960), Vol. 1, P.1, Oxford, p. 44

Kampp, F. (1996), DieThebanische Nekropole. Zum Wandel des Grabgedankens von der XVIII. bis zur XX. Dynastie, Theben, 13, Vol. I, Mainz, p. 215, Fig. 115.

El Shahawy, A. M. A. (2004), A Study of the Funeral Procession Scenes in the New Kingdom Nobles' Tombs in Thebes, Unpublished Thesis, Helwan University, Cairo, p. 82, Fig. 33.

\section{Plan 10}

Porter, B. and Moss, R. (1960), Vol. 1, P.1, Oxford, p. 208.

Kampp, F. (1996), DieThebanische Nekropole. Zum Wandel des Grabgedankens von der XVIII. bis zur XX. Dynastie, Theben, 13, Vol. I, Mainz, p. 380, Fig. 263.

Abu El Magd, A. M. (2006), A Study of Opening of the Mouth Ritual scenes in the Nobles' Tombs in Thebes (New Kingdom), Vol. 1, Text, Unpublished Thesis, Helwan University, Cairo, p. 126, Fig. 88.

Shedid, A. G. (1988), Stilder Grabmalereien in der Zeit Amenophis' II, Untersucht an den Thebanischen Gräbern Nr. 104 und Nr. 80, Mainz, Taf. 20, 21.

\section{Plan 11}

Porter, B. and Moss, R. (1960), Vol. 1, P.1, Oxford, p. 196.

Kampp, F. (1996), DieThebanische Nekropole. Zum Wandel des Grabgedankens von der XVIII. bis zur XX. Dynastie, Theben, 13, Vol. I, Mainz, p. 363, Fig. 243.

\section{Plan 12}

Porter, B. and Moss, R. (1960), Vol. 1, P.1, Oxford, p. 90.

Kampp, F. (1996), DieThebanische Nekropole. Zum Wandel des Grabgedankens von der XVIII. bis zur XX. Dynastie, Theben, 13, Vol. I, Mainz, p. 257, Fig. 150.

\section{Plan 13}

Porter, B. and Moss, R. (1960), Vol. 1, P.1, Oxford, p. 124.

Kampp, F. (1996), DieThebanische Nekropole. Zum Wandel des Grabgedankens von der XVIII. bis zur XX. Dynastie, Theben, 13, Vol. I, Mainz, p. 283, Fig. 171. 
El Shahawy, A. M. A. (2004), A Study of the Funeral Procession Scenes in the New Kingdom Nobles' Tombs in Thebes, Cairo, p. 66, Fig. 25.

\section{Plan 14}

Porter, B. and Moss, R. (1960), Vol. 1, P.1, Oxford, p. 124.

Davies, N. G. (1963), Scenes from Some Theban Tombs, Vol. IV, Oxford, Pl. XXIV.

\section{Plan 15}

Kampp, F. (1996), DieThebanische Nekropole. Zum Wandel des Grabgedankens von der XVIII. bis zur XX. Dynastie, Theben, 13, Vol. I, Mainz, p. 296, Fig. 182.

Hartwig, M. (2013), The Tomb Chapel of Menna (TT 69), Cairo, p. 2, Fig. 0.2.

Porter, B. and Moss, R. (1960), Vol. 1, P.1, Oxford, p. 136.

\section{Plan 16}

Kampp, F. (1996), DieThebanische Nekropole. Zum Wandel des Grabgedankens von der XVIII. bis zur XX. Dynastie, Theben, 13, Vol. I, Mainz, p. 268, Fig. 156.

Porter, B. and Moss, R. (1960), Vol. 1, P.1, Oxford, p. 106.

\section{Plan 17}

Porter, B. and Moss, R. (1960), Vol. 1, P.1, Oxford, p. 106.

Kampp, F. (1996), DieThebanische Nekropole. Zum Wandel des Grabgedankens von der XVIII. bis zur XX. Dynastie, Theben, 13, Vol. I, Mainz, p. 263, Fig. 153.

Davies, N. G. (1941), The Tomb of the Vizier Ramose, London, Pl. I.

\section{Plan 18}

Porter, B. and Moss, R. (1960), Vol. 1, P.1, Oxford, p. 400.

Kampp, F. (1996), DieThebanische Nekropole. Zum Wandel des Grabgedankens von der XVIII. bis zur XX. Dynastie, Theben, 13, Vol. I, Mainz, p. 583, Fig. 478. 


\section{Scenes}

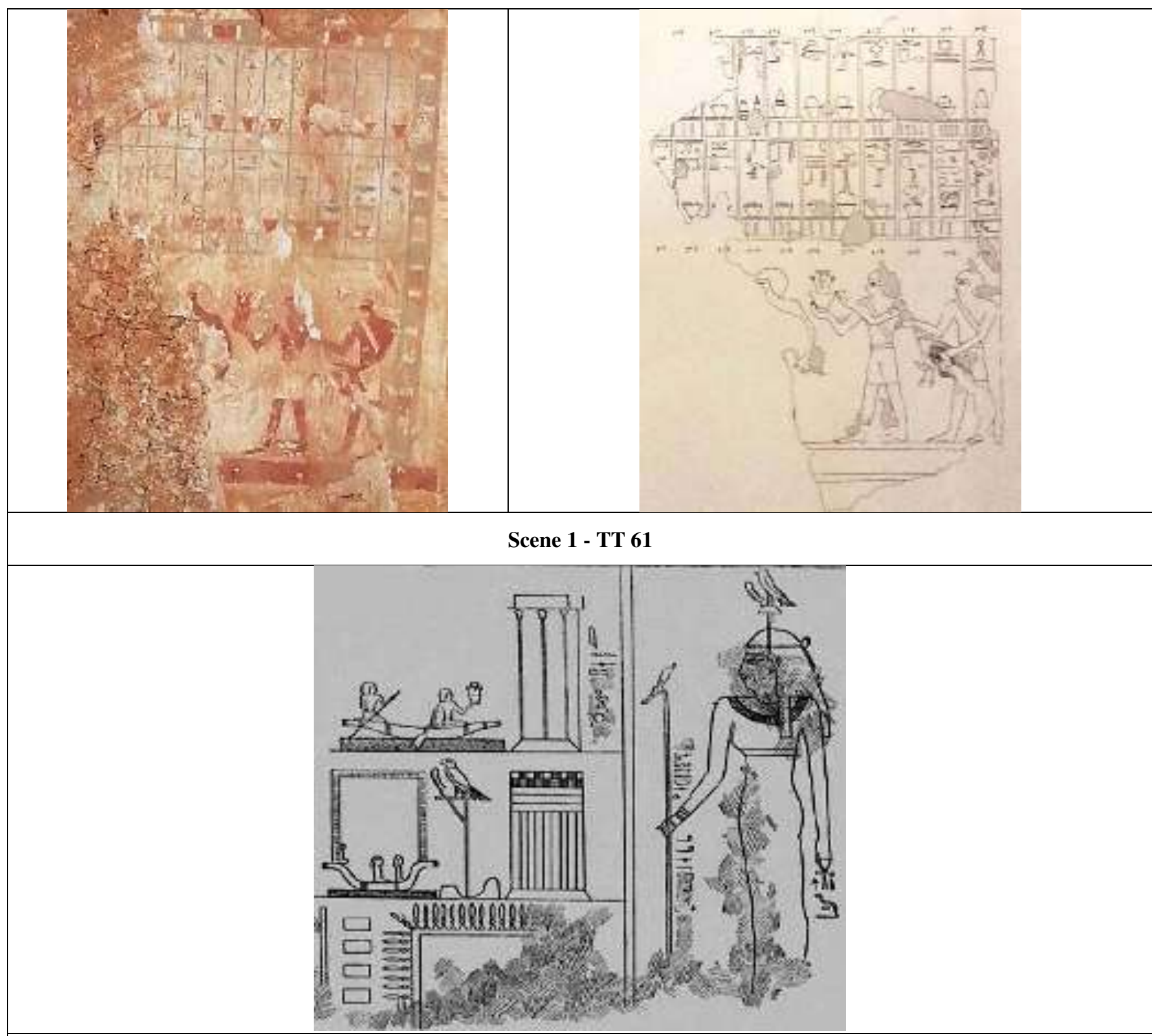

Scene 2 - TT 83

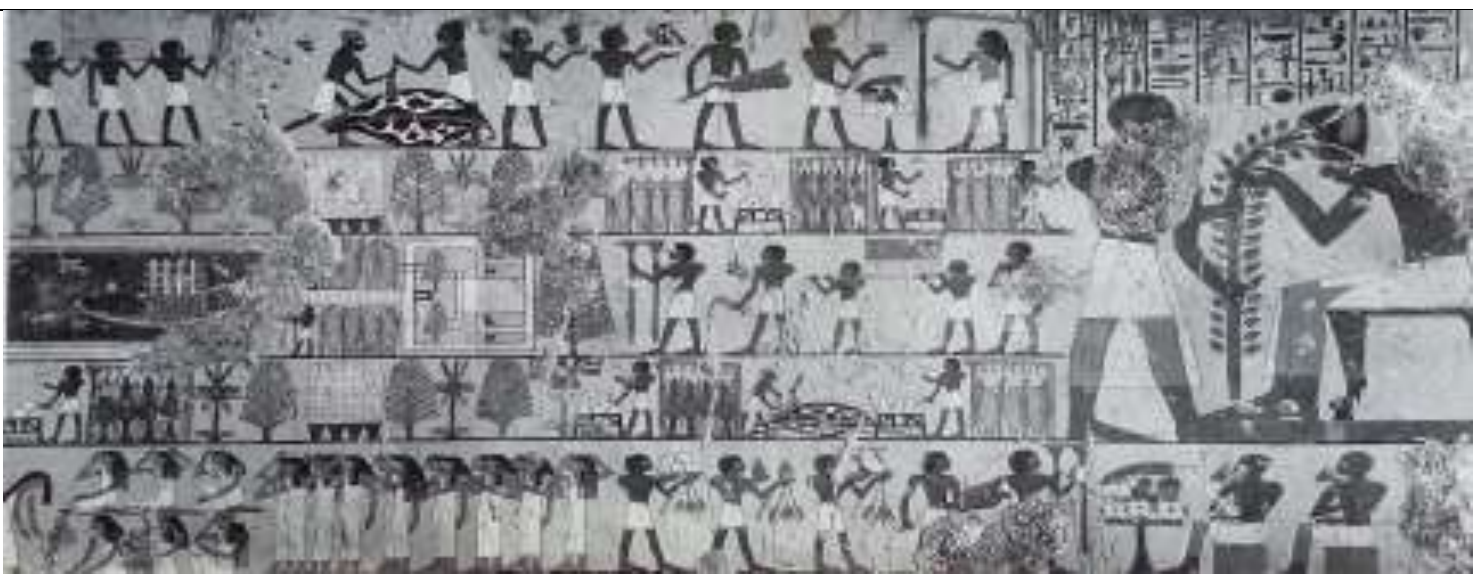

Scene 4 - TT87 


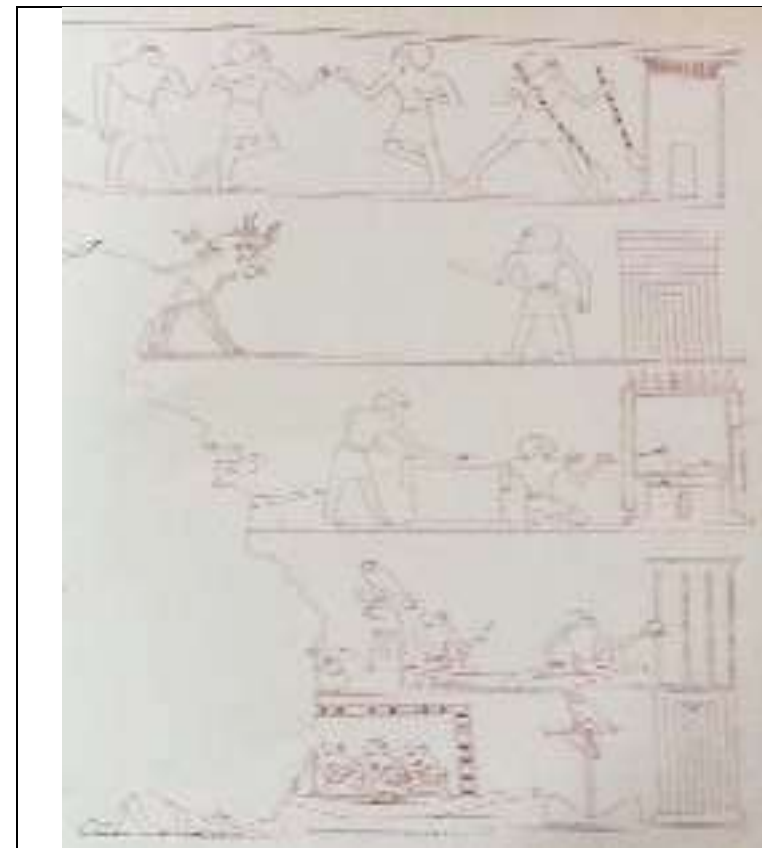

Scene 5 - TT42

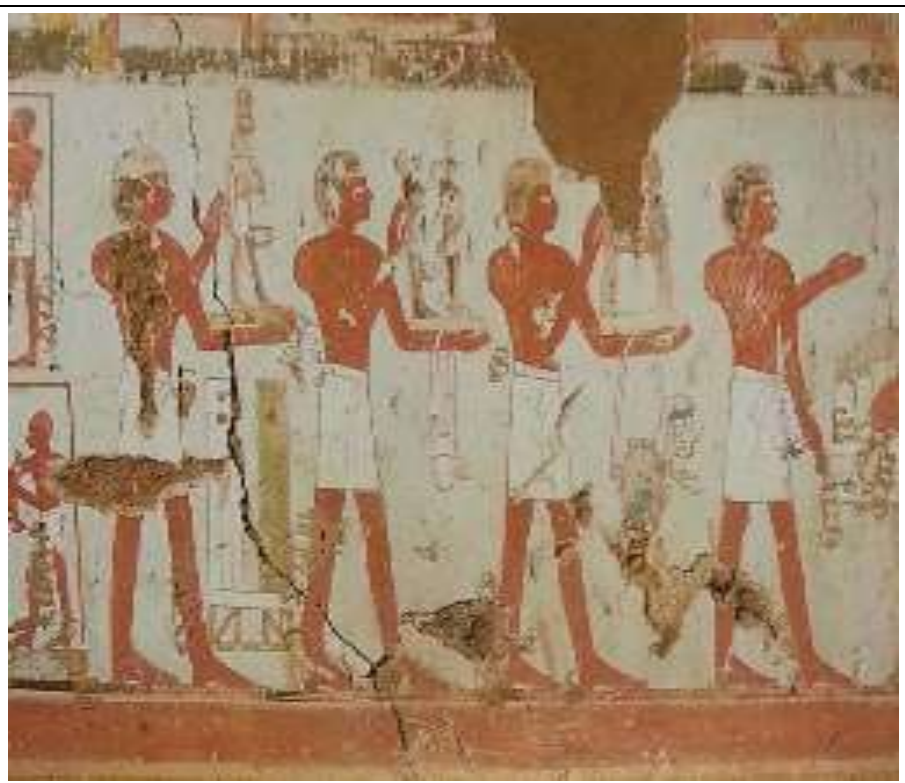

Scene 6 - TT79

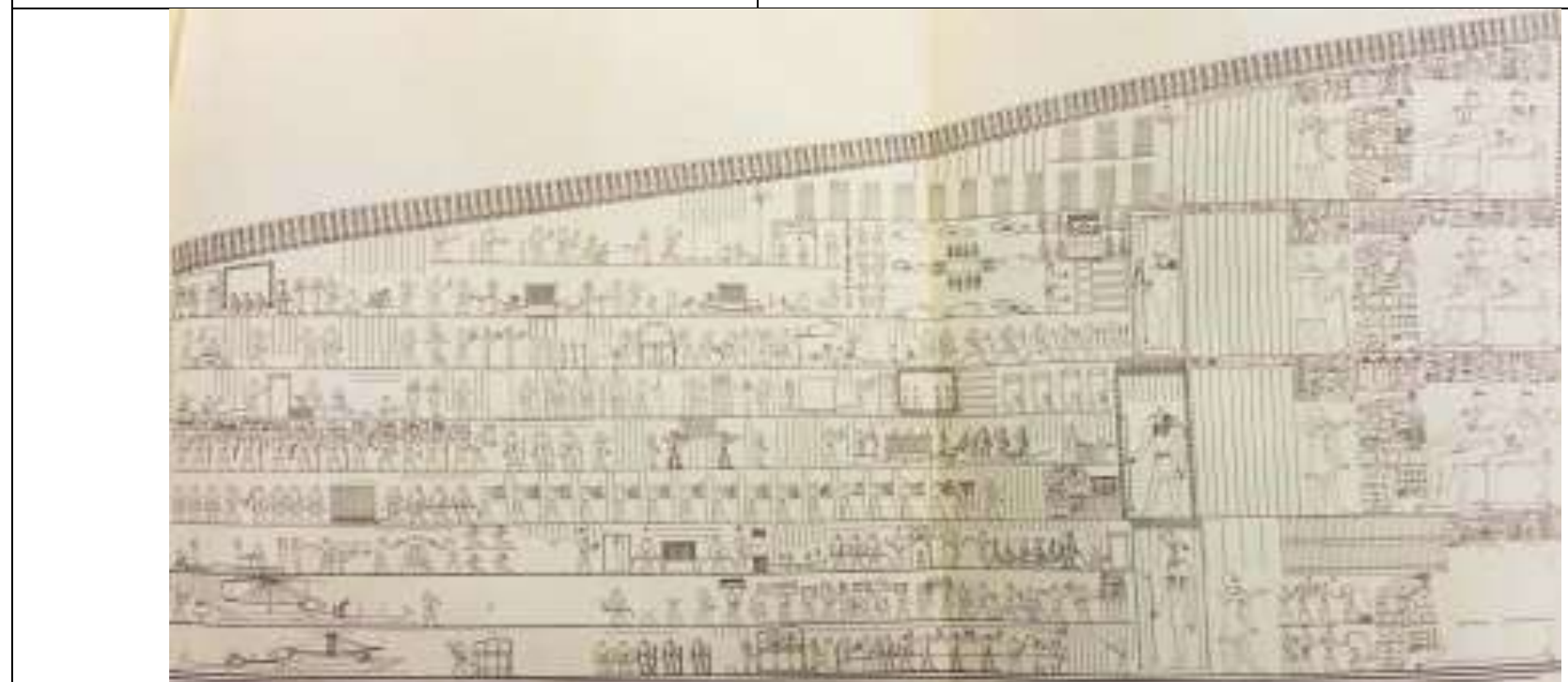

Scene 7a - TT100

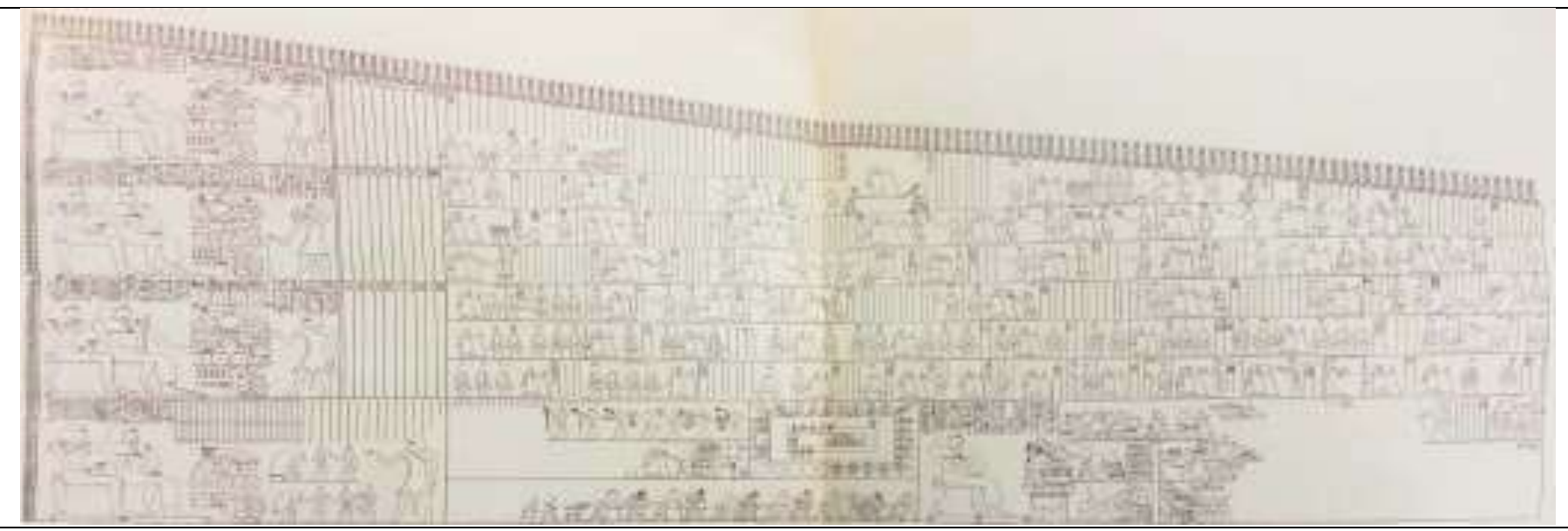

Scene 7b - TT100 


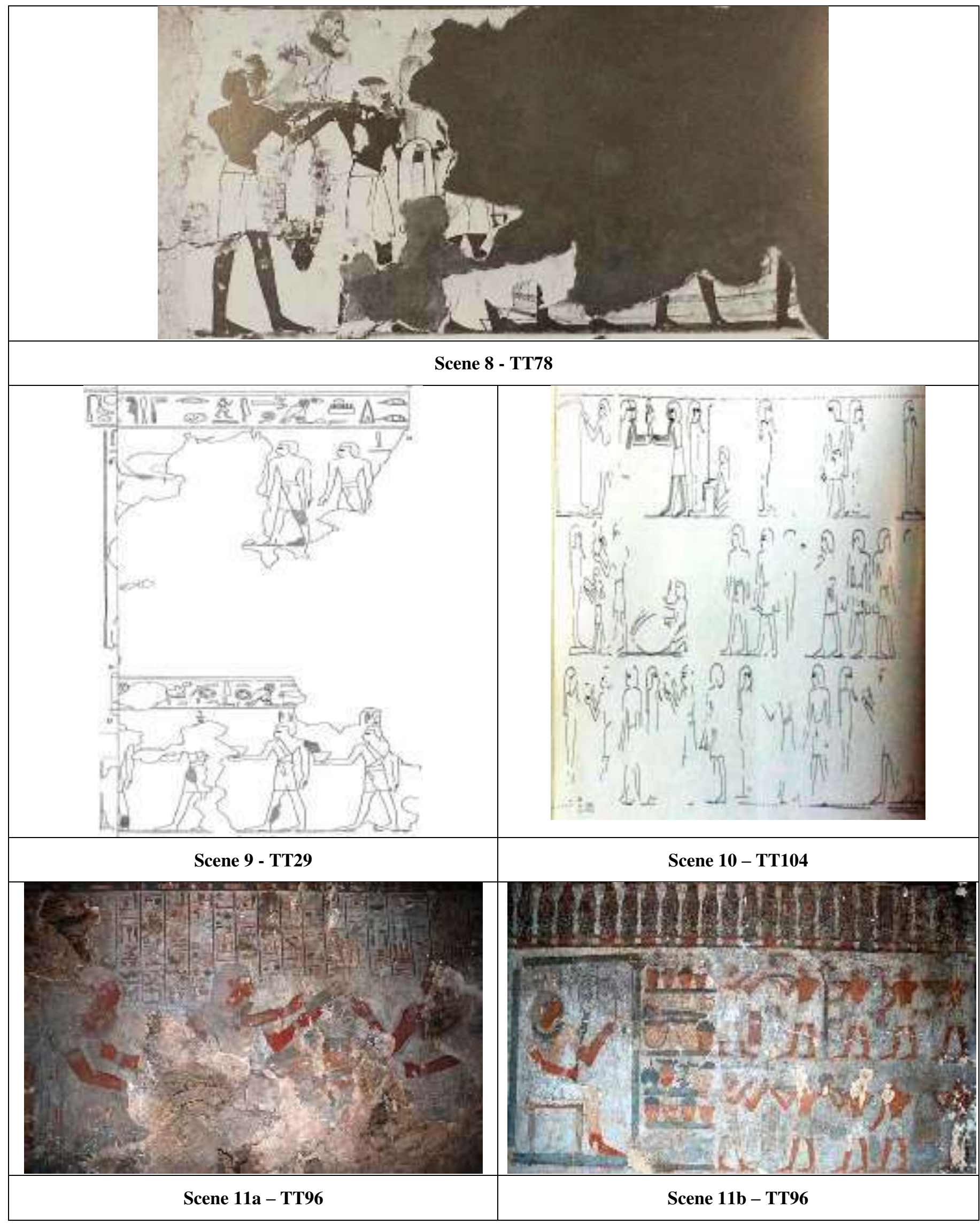


The Representation of Heart in Sheikh Abd El Qurna Private Tombs during the $18^{\text {th }}$ Dynasty

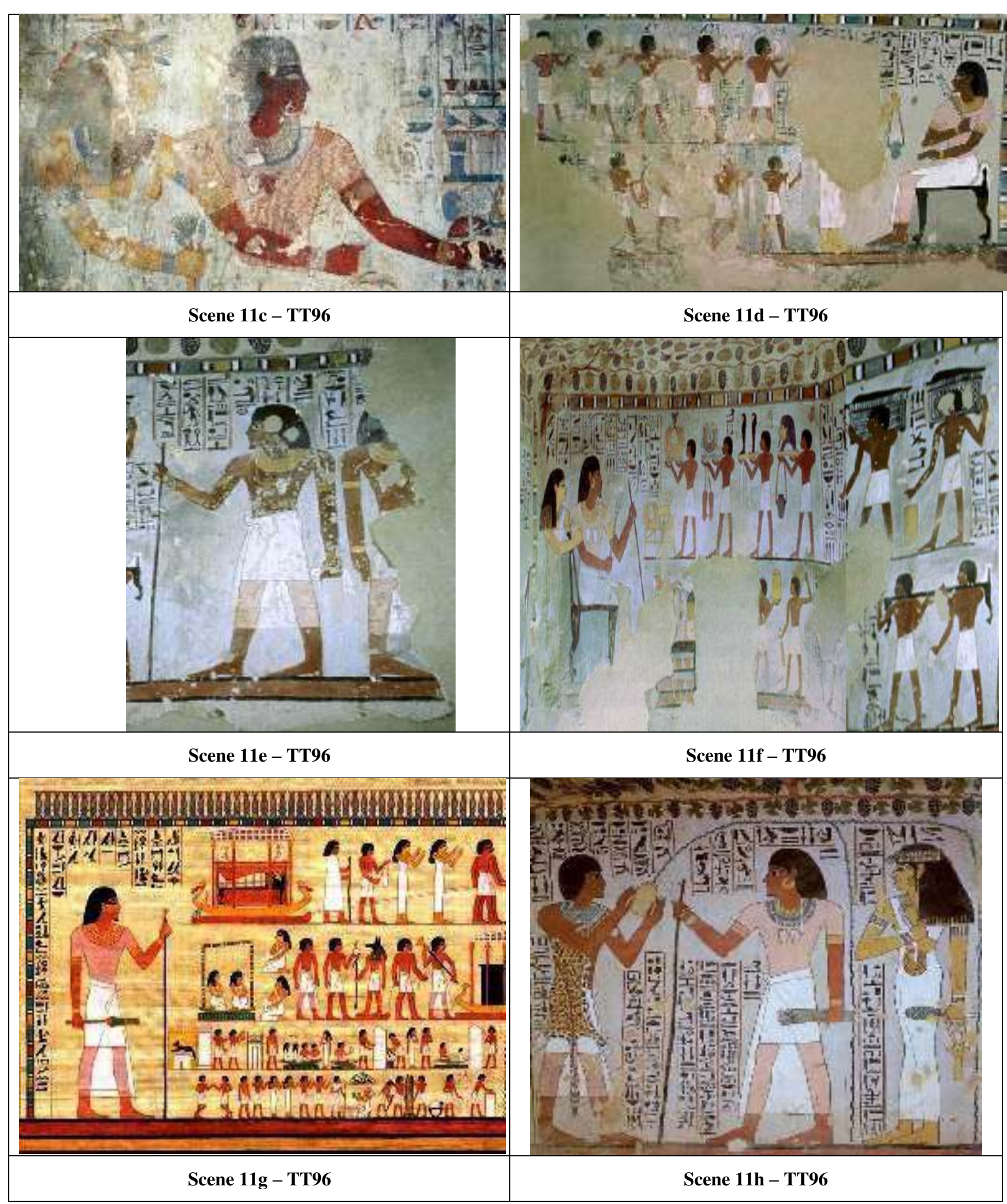




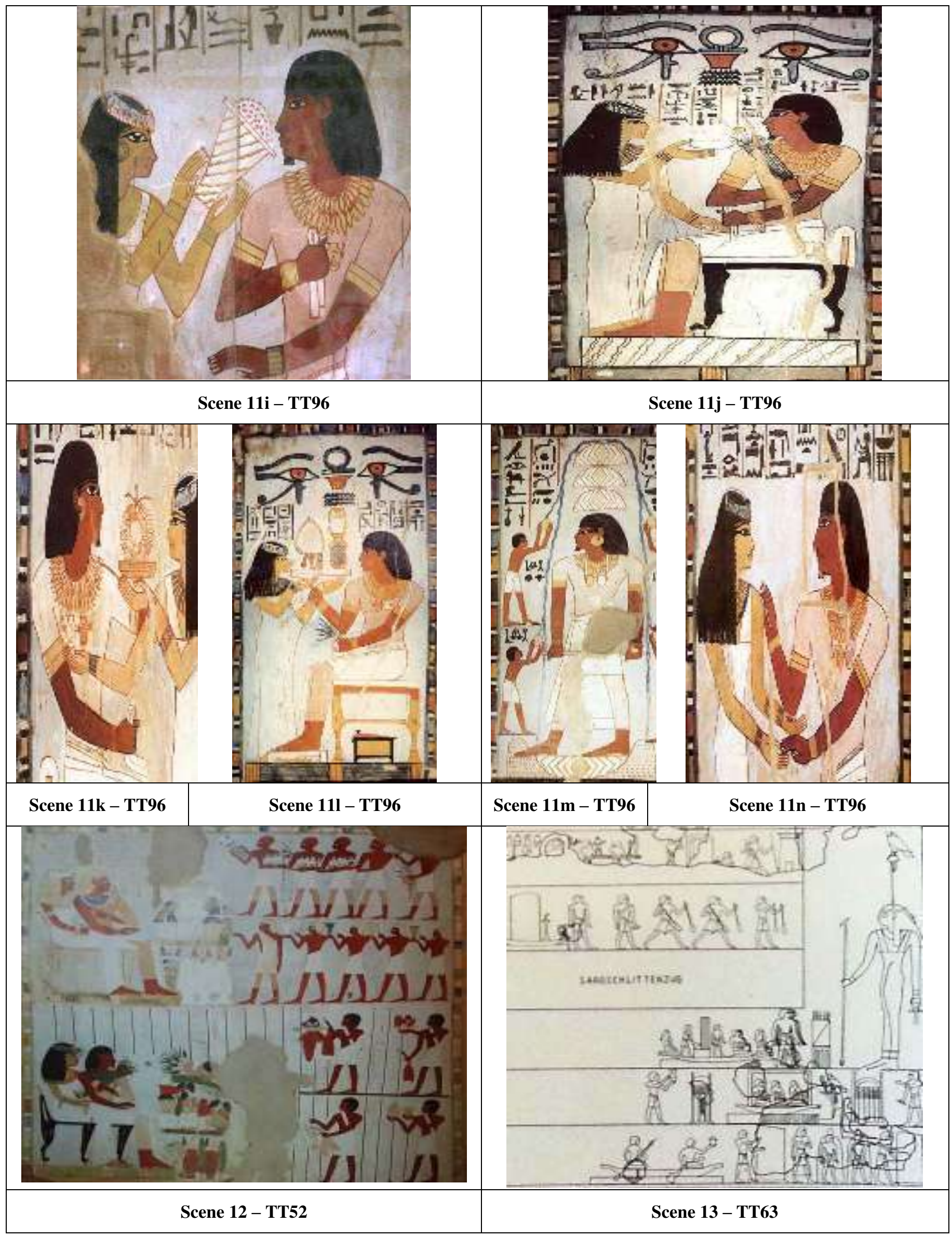




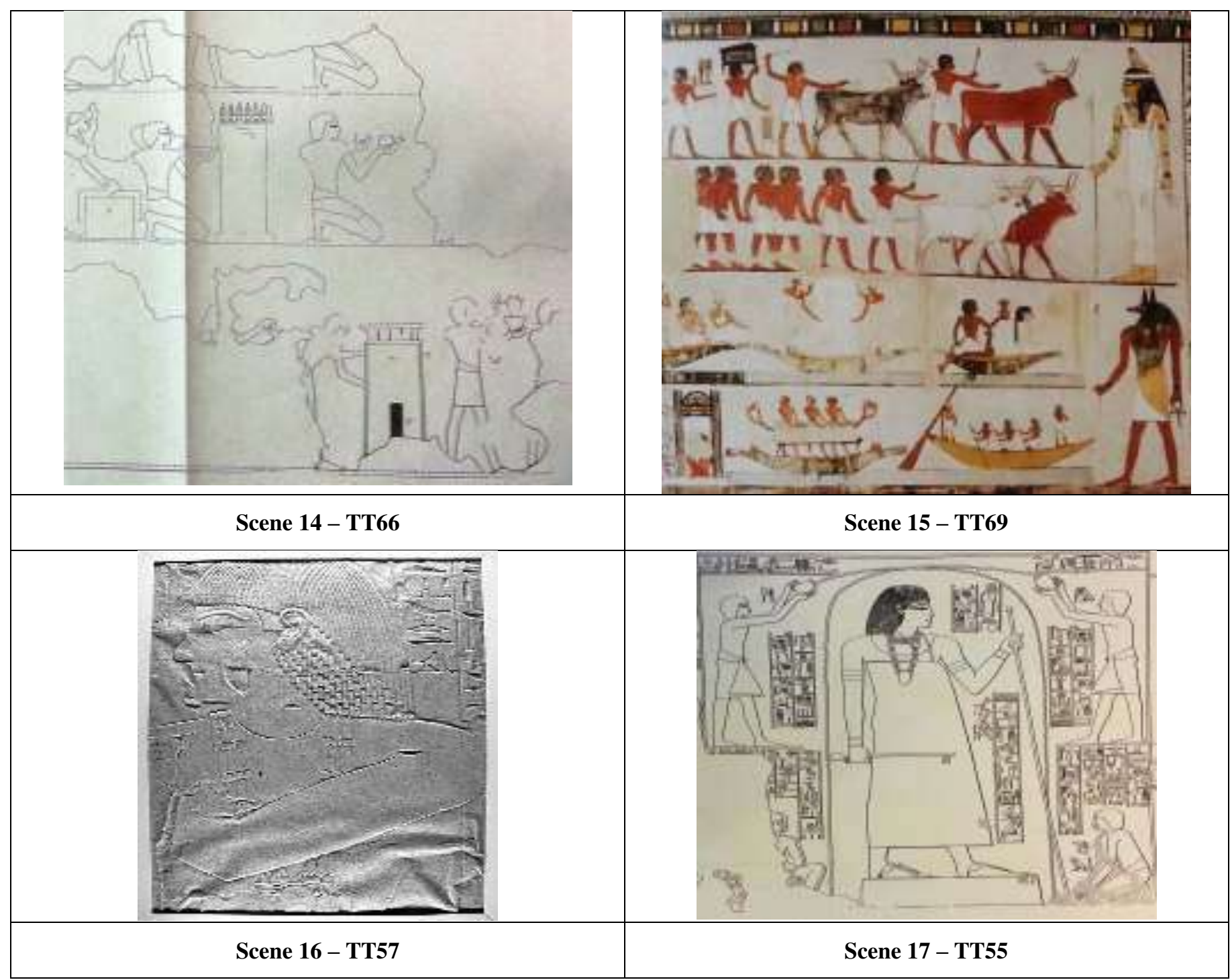

Plans 


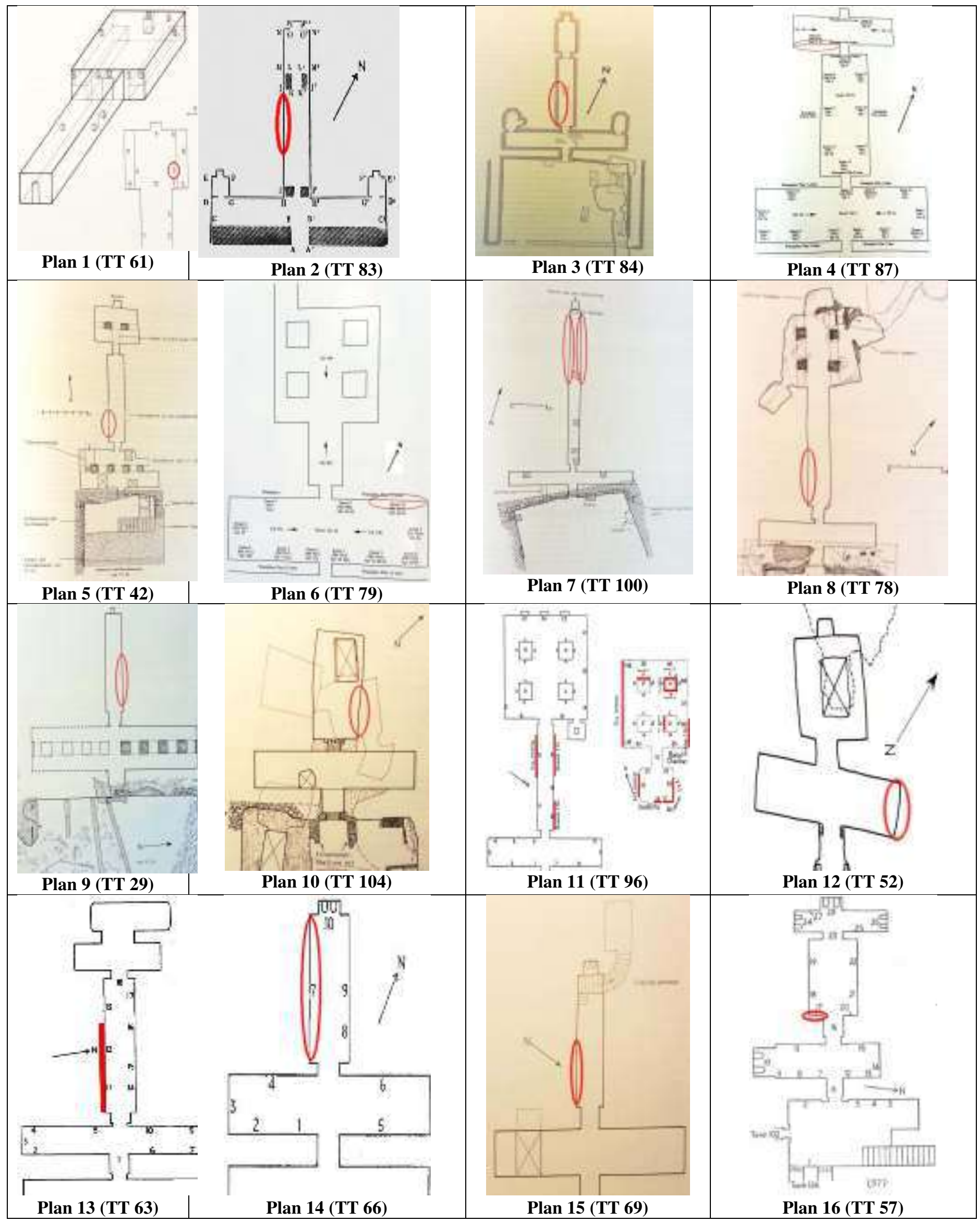



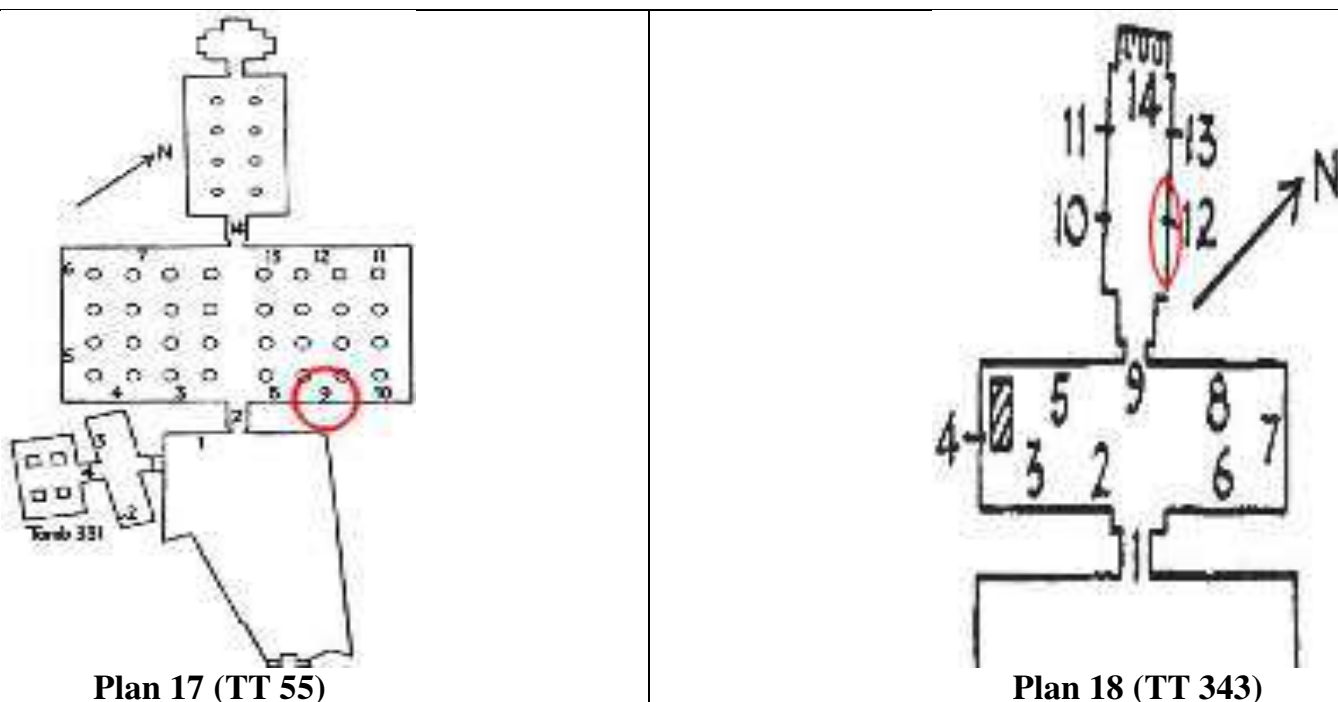

Plan 18 (TT 343)

1 عبد الرحيم محمد عبد المحسن طـيع (2009)، أشكال ورموز الأبديـة فيى مقابر أشـر اف الأسرة الثامنـة عشرة بطيبة الغربيـة، رسـالة

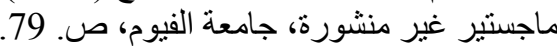

${ }^{2}$ Raven, M. J. (2012), Egyptian Magic, Cairo, pp. 153, 155, Fig. 127.

${ }^{3}$ Assman, J. (2001), Tod und Jenseits im Alten Ägypten, München, p. 104, Fig. 6;

Sharaf, L. A., op. cit; Wilkinson, R. H. (1992), Reading Egyptian Art, London, p. 77; عبد الرحيم محمد عبد) المحسن طايع ( 2013)، السمات الفنية والعمارية لمقابر أفر اد عصر الرعامسة بطيبة الغربية، رسـالة دكتور اه غير منشورة، جامعـة الفيوم،

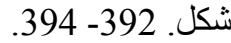

4 منال أحمد إير اهيم مسعود (1996)، العين عند المصرى القديم در اسة لغوية وأثريـة، رسـالة ماجستير غير منشورة، جامعة الإسكندرية،

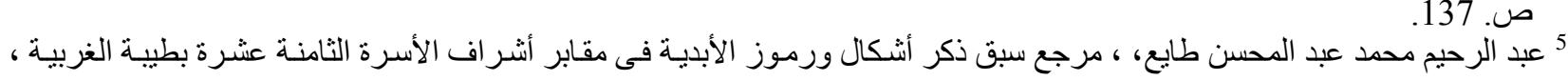

${ }^{6}$ Polz, D. C. (2001), Thebes, in: The Oxford Encyclopedia of Ancient Egypt, Vol. III, Oxford, p. 387.

${ }^{7}$ Bard, K. A. (2007) An Introduction of Archaeology of Ancient Egypt, Blackwell Publishing, USA, p. 250.

${ }^{8}$ Abu El Magd, A. M. (2006), A Study of Opening of the Mouth Ritual Scenes in the Nobles' Tombs in Thebes (New Kingdom), Unpublished Thesis, Helwan University, Vol.1, Cairo, p. 207.

${ }^{9}$ Loc. cit.

${ }^{10}$ Klasens, A. (1975), Amulet, in: Leixkon Der Ägyptologie, Vol.1, Wiesbaden, p. 232; Mahmoud, M. R. M. (2004), Human Fertility in Ancient Egypt, Unpublished Thesis, Helwan University, Cairo, p. 237.

${ }^{11}$ Klasens, A., Ibid; Andrews, K. (1994), Amulets of Ancient Egypt, London, p. 6; Andrews, C. (2001), Amulets, in: The Oxford Encyclopedia of Ancient Egypt, Vol. 1, Oxford, p. 75; Howes, M. (1975), Amulets, London, p.30.

${ }^{12}$ Klasens, A., Ibid; Mahmoud, M. R. M., op. cit.

${ }^{13}$ Sousa, R. (2008- 2010), Animal and Human Headed Heart Amulets: Symbolism and Meaning, in: Bulletin De La Société D' Égyptologie, Vol. 28, Genève, p. 129.

${ }^{14}$ Sousa.R, F.(2007), The Heart Amulet in Ancient Egypt: A Typological Study, in: Proceedings of the Ninth International Congress of Egyptologists, Leuven, p. 713; Klasens, A., op. cit; Mahmoud, M. R. M., op. cit.

${ }^{15}$ Mahmoud, M. M. R., Ibid., p. 238.

Ratié, S. (1964), Le Scarabée de Coeur du Musée D'Annecy, in: BIFAO, Vol. LXII, Cairo, p.109; دهام حسين يونس محمد، مرجع سبق ذكره، ص. 78.

${ }^{16}$ Lekov,T., op. cit.

${ }^{17}$ Bonnet, H., op. cit., pp. 28, 30, Fig. 10 (2).

${ }^{18}$ Mahmoud, M. M. R. op. cit., p. 238; .78 الهام حسين يونس محمد، مرجع سبق ذكره، ص.

${ }^{19}$ Sousa, R., op. cit., p. 5.

${ }^{20}$ Sousa, R. (2009), Symbolism and Meaning of Pendulum Heart Amulets, in: Göttinger Miszellen, Vol. 221, Göttingen, p. 69; Sousa, R. (2010), Symbolism and Meaning of the Cornice Heart Amulets, in: Chronique 
D' Égypte, Vol. LXXXV, fasc. 169 -170, Brussel, p. 81; Sousa, R. (2007), The Meaning of the Heart Amulets in Egyptian Art, in: JARCE 43, Cairo, p. 59.

${ }^{21}$ Sousa, R., Ibid., p. 91.

${ }^{22}$ Levinson, H. and Levinson, A. (2001), Venerated Beeltles and their Cultural Historical- Background in Ancient Egypt, in: Spixiana, Vol. 27, p. 61, Fig. C.

${ }^{23}$ Lurker, M., op. cit., pp. 34, 35.

${ }^{24}$ Assman, J., op. cit., p. 139.

${ }^{25}$ Sharaf, L. A., op. cit., p. 401; Allan, T. G. (1974), The Book of the Dead or Going Forth by Day, London, p. 37; عبد الرحيم محمد عبد المحن طايع ، أثكال ورموز الأبدية فى مقابر أشر اف الأسرة الثامنة عشرة بطيبة الغربية، مرجع سبق ذكره، ص.80.

${ }^{26}$ Buzov, E. (2005), The role of the heart in the purification, in: L'Acqua nell'antico Egitto, Roma, p. 5.

${ }^{27}$ Meulenaere, H. (1972), Scarabaeus Sacer, Belgium, p. 26; Taylor, J. H. (2010), Spells for Eternity (The Ancient Egyptian Book of the Dead), London, p. 61; Allan, T. G., op. cit., p. 38; عبد الرحيخ محمد عبد المحسن طايع أشكال ورموز الأبدية فى مقابر أشر اف الأسرة الثامنة عشربطيبة الغربية، مرجع سبق ذكره، ص.80.

${ }^{28}$ Allan, T. G., Ibid., p. 39.

${ }^{29}$ Mahmoud, M. M. R., op. cit., p. 238.

Lorand, D. (2008), Quatre scarabees de coeur inscrits a tete humaine, in: Chronique d'Égypte, Vol.

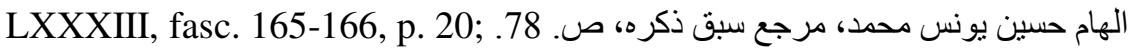

${ }^{30}$ Mahmoud, M. M. R., op. cit., pp. 238, 239; Allan, T. G., op. cit, pp.39, 40.

Lurker, M., op. cit., pp. 34, 35; Sharaf, L. A., op. cit., p. 411; Wilkinson, R. H., Reading Egyptian Art, op. cit., p. 7; Gee, J. (2009), Of Heart Scarabs and Balance Weights: A New Interpretation of Book of the Dead 30 B, in: The Journal of The Society for the Study of Egyptian Antiquities ,Vol. XXXVI, pp. 1- 15; عبد الرحيم محمد عبد المحسن طايع ،أشكال ورموز الأبدية فى مقابر أثر اف الأسرة الثامنة عشرة بطيبة الغربية، مرجع سبق ذكره، ص.80.

${ }^{31}$ Allan, T. G., Ibid., p. 97; Faulkner, R. O, (1990), The Ancient Egyptian Book of the Dead, Austin, p. 29. 34; Taylor, J. H., op. cit., pp. 98 -100; Andrews, K., Amulets of Ancient Egypt, op. cit., p. 56; Quirke, S. (2001), Judgment of the Dead, in: The Oxford Encyclopedia of Ancient Egypt, Vol. II, p. 213; Ratié, S. (1968), Le Papyrus de Neferoubenef ( Louvre III 93), in: Bibliotheque D'Étude, Vol. XLIII, Cairo, p. 51,

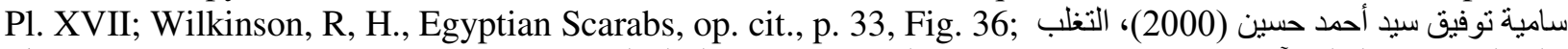

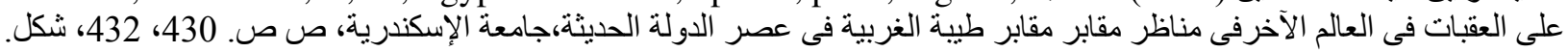

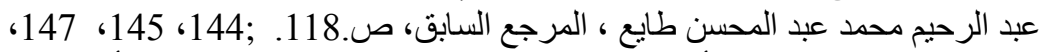

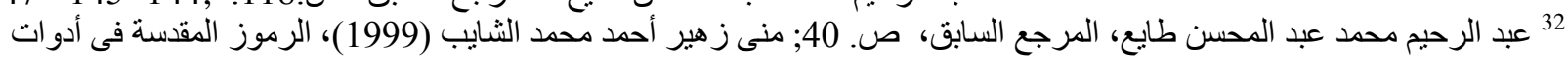

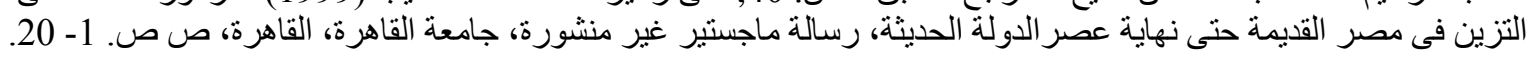

${ }^{33}$ Derchain, P. (1976), Symbols and Metaphors in Literature and Representations of Private Life, in: RAIN,

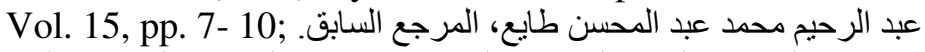

34 تامر أحمد فؤاد أحمد الرشيدى(2004)، رمزية الألوان ودلالاتها فى العمارة و الفنون المصرية القديمة حتى العى نهاية العصور الدصرية القديمة

${ }^{35}$ Lurker, M., op. cit., p. 41.

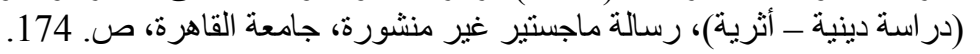

${ }^{37}$ Gardiner, A., op. cit., pp. 597, 607.

$$
36 \text { نامر أحمد فؤاد أحمد الرشيدى، مرجع سبق ذكره، ص ص. } 299 .
$$

${ }^{38}$ Sharaf, L. A., op. cit., p. 397; Wilkinson, R. H. (1994), Symbol and Magic in Egyptian Art, London, p. 109.

${ }^{40}$ Lurker, M., op. cit., p. 34.

39 تامر أحمد فؤاد أحمد الرشيدى، مرجع سبق ذكره، ص.303.

${ }^{41}$ Gomaa, F. (2001), Upper Egypt, in: The Oxford Encyclopedia of Ancient Egypt, Vol. III, p. 464.

${ }^{42}$ Lurker, M., op. cit., p. 41.

${ }^{43}$ Gardiner, A., op. cit., pp. 471, 603, 622.

${ }^{44}$ Lurker, M., op. cit., pp. 7, 100.

${ }^{45}$ Ibid., p. 41; Sharaf, L. A., op. cit., p. 398.

${ }^{46}$ Griffith, J. G. (1972), The Symbolism of Red in Egyptian Religion, in: Ex Orbe Religionum Studia Geo Widengren, Vol. I, Leiden, 1972, pp.82- 84.

${ }^{47}$ https://www.academia.edu/4749918/Red_Colour_in_expressing_anger_in_ancient_Egyptian_Texts, Abo el Magd, A., Red Colour in expressing anger in ancient Egyptian Texts (Last Accessed 12/06/2016) 
${ }^{48}$ Sharaf, L. A., op. cit., p. 398; Lurker, M., op. cit., p. 100; Hussein, M, I. (1998), The Symbolism of the Double Crown 'A Psycho - Mythological Study', in: Discussions in Egyptology, Vol. 41, Oxford, p. 40.

${ }^{50}$ Lurker, M., op. cit., p. 41. 49 تامر أحمد فؤاد أحمد الرشيدى، مرجع سبق ذكره، ص.303.

${ }^{51}$ Gardiner, A., op. cit., p. 583.

${ }^{52}$ Hussein, M, I., op. cit., p. 40.

${ }^{53}$ Sharaf, L. A., op. cit., p. 398.

${ }^{54}$ Loc. cit.

${ }^{56}$ Sharaf, L. A., op. cit., p. 398.

55 تامر أحمد فؤاد أحمد الرشيدى، مرجع سبق ذكره، ص.304.

${ }^{57}$ Gardiner, A., op. cit., p. 586; Brunner-Traut, T. (1977), Farben, in: Lexikon Der Ägyptologie, Vol. II, p. 119; Robins, G. (2001), Color Symbolism, in: The Oxford Encyclopedia of Ancient Egypt, Vol. 1, p. 292.

${ }^{58}$ Robins, G., Ibid; Lurker, M., op. cit., p. 41.

${ }^{59}$ Dziobek, E. (1994), Die Graber des Vezirs User-Amun Theben Nr. 61 und 131, Mainz, pp. 21, 27, 28; Porter, B. and Moss, R. (1960), Vol. 1, P.1, Oxford, p. 125 (no. 9) .

${ }^{60}$ Virey, PH. (1891) Sept Tombeaux Thébains de la XVIIIe Dynastie, (MMAF 5, 2), Paris, pp. 348, 349.

${ }^{61}$ Virey, PH. (1889) Sept Tombeaux Thébains de la XVIIIe Dynastie, (MMAF 5, 1), Paris, p. 70.

${ }^{62}$ Virey, PH., op. cit., p. 349.

${ }^{63}$ El Shahawy, A. M. A. (2004), A Study of the Funeral Procession Scenes in the New Kingdom Nobles' Tombs in Thebes, Unpublished Thesis, Helwan University, Cairo, p. 35.

${ }^{64}$ Loc. cit; Settgast, J. (1963), Untersuchungen Zu Altägyptischen Bestattungsdarstellungen, New York, pp. 82-88, Taf. 8.

${ }^{65}$ El Shahawy, A. M. A., Ibid; Porter, B. and Moss, R., op. cit., p. 169 (no. 13).

${ }^{66}$ Abu El Magd, A. M., op. cit., p. 113; Porter, B. and Moss, R., Ibid.

${ }^{67}$ Porter, B. and Moss, R., Ibid., p. 179 (no. 8).

${ }^{68}$ Davies, N, G. and Davies, N. G. (1933), The Tombs of Menkheperrasonb, Amenmose and Another, London, p. 33; Porter, B. and Moss, R., Ibid., p. 83 (no. 14).

${ }^{69}$ Porter, B. and Moss, R., Ibid., p. 157 (no. 7).

${ }^{70}$ Ibid., p. 212 (no. 15, 16); David, N. G. (1943), The Tomb of REH-MI-REa at Thebes, Vol. 1, New York, p. 70

$$
\begin{aligned}
& 71 \text { عبد الرحيم محمد عبد المحسن طايع، أثنكال ورموز الأبدية فى مقابر أثر اف الأسرة الثنامنة عشرة بطيبة الغربية، مرجع سبق ذكره، . } \\
& \text { ص 82، شكل 109 الرحم } 109 . \\
& 72 \text { عبد الرحيم محمد عبد المحسن طايع، المرجع السابق، ص 82، شكل } 108 .
\end{aligned}
$$

${ }^{73}$ Porter, B. and Moss, R., op. cit., p. 212 (no. 15, 16).

${ }^{74}$ Ibid., p. 214 (no. 19, 20).

${ }^{75}$ Muhammed, M. A. (1966), The Development of the Funerary Believes and Practices Displayed in the Private Tombs of the New Kingdom at Thebes, Cairo, p. 172; Dorman, P. (2001), Rekhmire, in:The Oxford Encyclopedia of Ancient Egypt, Vol. III, Oxford, P. 132.

${ }^{76}$ Porter, B. and Moss, R., op. cit., p. 154, (no. 9); Bourian, U. (1894), Tombeaux Thebaines, MMAF (5, 3), Paris, p. 431; El Shahawy, A. M. A., op. cit., p.63, Pl. 82 (not found).

${ }^{77}$ El Shahawy, A. M. A., Ibid., p. 63; Porter, B. and Moss, R., Ibid., p. 46, (no.9). Davies, N. G. (1913), Five Theban Tombs, London, p. 16, note 4.

${ }^{78}$ Porter, B. and Moss, R., Ibid., p. 218, (no.10).

${ }^{79}$ Abu El Magd, A. M., op. cit., p. 126. Pls. XLVIII, XLIV (not found).

${ }^{80}$ Porter, B. and Moss, R., op. cit., p. 198 (no. 12).

${ }^{81}$ Ibid., p. 199 (no. 13, 15).

${ }^{82}$ Ibid., p. 200 (no. 25, 27-28).

${ }^{83}$ Ibid., p. 200 (no. 26).

${ }^{84}$ Ibid., p. 201(no. 33-34); El Shahawy, A. M. A., op. cit., p. 91.

${ }^{85}$ Porter, B. and Moss, R., Ibid., p. 201(no. 36); Abu El Magd, A. M., op. cit., p. 118.

${ }^{86}$ Porter, B. and Moss, R., Ibid., p. 202.

${ }^{87}$ Ibid., p. 203.

${ }^{88}$ Ibid., p. 202. 
${ }^{89}$ Ibid., p. 101, (no.5); Davies, N. G. (1917), The Tomb of Nakht at Thebes, New York, pp. 53-55.

${ }^{90}$ Porter, B. and Moss, R. , Ibid., p. 127, (no. 11.12); El Shahawy, A. M. A., op. cit., pp. 66, 67; Deziobek, E and Abd Elraziq, M (1990), Das Grab des Sobekhotep Theben Nr. 63, Mainz, p.33, Szenen, 14,15.

${ }^{91}$ Porter, B. and Moss, R., Ibid., p. 132, (no. 7); Davies, N. G. (1963), Scenes from Some Theban Tombs,

Vol. IV, Oxford, p. 12; عبد الرحيم محمد عبد المحسن طايع ،أنكال ورموز الأبدية فى مقابر أشراف الأسرة الثامنة عشرة بطيبة

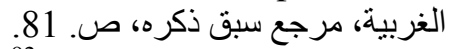

عبد الرحيم محمد عبد المحسن طايع، المرجع السابق، ص.82.

${ }^{93}$ Ibid., p. 117, (no.17)

${ }^{94}$ Ibid., p. 109, (no. 9); Davies, N. G. (1941), The Tomb of the Vizier Ramose, London, 19.

${ }^{95}$ Abu El Magd, A. M., op. cit., p. 153, (no.12).

${ }^{96}$ Muhammed, M. A., op. cit., p.161.

عبد الرحيم محمد عبد المحسن طايع، السمات الفنية والعمارية لدقابر أفر اد عصر الرعامسة بطيبة الغربية، مرجع سبق ذكره، ص. 298. 97

${ }^{98}$ Abu El Magd, A. M., op. cit., p. 2; Buzov, E. (2005), The role of the heart in the purification, in: L'Acqua nell'antico Egitto, Roma, pp. 1- 7; . 305 المرجع السابق، ص.

${ }^{100}$ Abu El Magd, A. M., op. cit., p. 10,11, Fig. 26,43.

$$
99 \text { المرجع السابق، ص. } 306 .
$$

101

المرجع السابق، ص ص، 303، 304.

${ }^{103}$ Ibid., p. 161.

105 104 عبد الرحيم محمد عبد المحسن طايع،السمات الفنية والعمارية لمقابر أفر اد عصر الرعامسة بطيبة الغربية، مرجع سبق ذكره، ص. 283.

${ }^{106}$ Bard, K. A. (2007) An Introduction of Archaeology of Ancient Egypt, Blackwell Publishing, USA, p. 252.

${ }^{107}$ Dodson, A. (2001), Private Tombs, in: The Oxford Encyclopedia of Ancient Egypt, Vol. III, pp. 434,437.

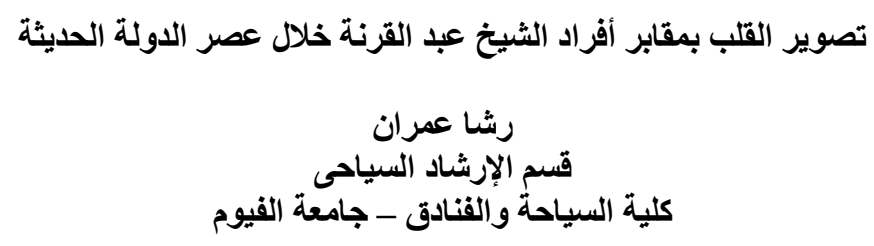

الملخص العربى

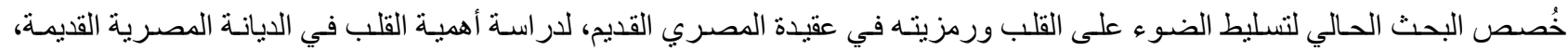

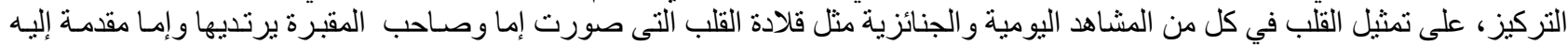

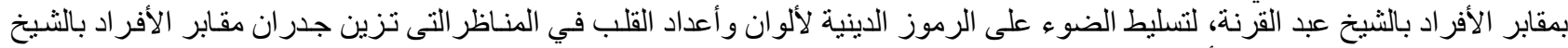

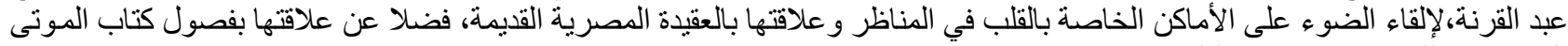

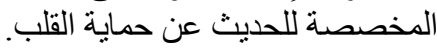

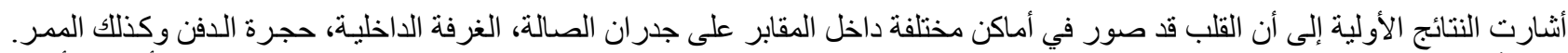

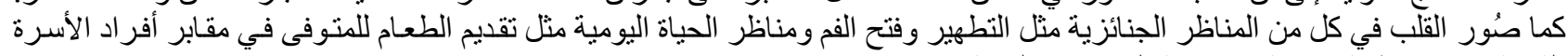
الثامنة عشرة بطيبة خاصة في جبانة الثيخ عبد القرنة.

الكلمات الدالة: القلب، الثيخ عبد القرنة ، مصر القديمة، مناظر جنائزية، مناظر الحياة اليومية، الرمزية الدينية، مقابر الأفر اد، الدولة الحديثة. 